University of Chicago Law School

Chicago Unbound

Journal Articles

Faculty Scholarship

Fall 1963

\title{
The Economics and Law of Price Discrimination: Herein of Three Regulatory Schemes
}

Kenneth W. Dam

Follow this and additional works at: https://chicagounbound.uchicago.edu/journal_articles

Part of the Law Commons

\section{Recommended Citation}

Kenneth W. Dam, "The Economics and Law of Price Discrimination: Herein of Three Regulatory Schemes," 31 University of Chicago Law Review 1 (1963).

This Article is brought to you for free and open access by the Faculty Scholarship at Chicago Unbound. It has been accepted for inclusion in Journal Articles by an authorized administrator of Chicago Unbound. For more information, please contact unbound@law.uchicago.edu. 


\title{
THE \\ UNIVERSITY OF CHICAGO LAW REVIEW \\ VOLUME 31 \\ FALL 1963 \\ NUMBER 1
}

\section{THE ECONOMICS AND LAW OF PRICE DISCRIMINATION: HEREIN OF THREE REGULATORY SCHEMES*}

\author{
KENNETh W. DAM†
}

B ECAUSE OF an unfortunate coincidence of labels, price discrimination in law is often confused with price discrimination in economics. Legislation against price discrimination is sometimes thought to regulate the practice of what may be called economic discrimination. ${ }^{1}$

The confusion is unfortunate. Since economic discrimination is generally thought to contribute to misallocation of resources in the economy and to constitute a perquisite of economic power enjoyed at the expense of the public, it is natural to suppose that, whatever may be said about anti-discrimination legislation, one of its merits is that it tends to reduce the incidence of an undesirable economic phenomenon. In discussions of the Robinson-Patman Act, for example, the felt need for maintaining some restrictions on economic discrimination tends to dampen demands for outright repeal.

The purpose of the inquiry undertaken here is simple. It is to determine whether anti-discrimination legislation operates to restrict economic discrimination. If it should be the case that anti-discrimination

- The author wishes to thank Professor Paul W. MacAvoy for his many helpful comments and suggestions based on the reading of an early draft of this article.

+ Associate Professor of Law, The University of Chicago.

1 To avoid confusion between the legal concept and the economic phenomenon of price discrimination, the latter will from time to time be referred to herein as economic discrimination. Alternative references to price discrimination and rate discrimination are not meant to suggest any inherent economic difference but rather constitute simply a stylistic concession to the widespread convention of using the former to refer to economic discrimination in the sale of goods and the latter to economic discrimination in the sale of transportation and electric power. 
legislation has little to do with economic discrimination, or if indeed that such legislation tended to encourage or even require economic discrimination, then the merits of such legislation could be more simply assessed. Such legislation could then be evaluated on the basis of whatever social and political values it might be thought to reflect. Professor Corwin Edwards, for example, views the Robinson-Patman Act as a "political" statute embodying the "democratic ideal" that "so far as private persons have the power to affect substantially the rights and opportunities of their fellows ... they [as well as "persons exercising political and judicial authority"] have a duty to treat their fellows equally." 2 Some supporters have asserted that the Robinson-Patman Act is the legislative embodiment of a "constitutional freedom-equality of oppor-" tunity" 3 while the "Magna Carta" metaphor has seemed compelling to others. ${ }^{4}$ Representative Patman has suggested that an appropriate reference is to the "Golden Rule."5

In undertaking this inquiry no attempt shall be made to review all the state and federal statutes which in one form or another purport to proscribe discrimination in prices and rates. Enlightening as such a review might prove in revealing the pervasive attraction of such measures for legislators, it would be an unwieldy task. On the other hand, it would be a mistake to limit attention to a single statute where the political factors which led to the legislation or its particular mode of enforcement might be considered as an explanation of any divergence

2 Edwards, The Price Discrimination Law 1 (1959).

3 Patman, Complete Guide to the Robinson-Patman Act 197 (1963), sets out a statement made Dec. 16, 1953 to the Attorney General's National Committee to Study the Antitrust Laws by the National Association of Retail Grocers, the National Association of Retail Druggists, the National Association of Independent Tire Dealers, Inc., the National Congress of Petroleum Retailers, Inc., the United Fresh Fruit and Vegetable Association, the National Food Brokers Association, the National Candy Wholesalers Association, Inc. and the United States Wholesale Grocers' Association, Inc.: "Constitutional freedom-equality of opportunity-of the people to engage in trade or business, is the essential concern of the national antitrust policy . . .."

4 Patman quotes a witness for the National Farmers Union saying: "The RobinsonPatman Act has been referred to as the Magna Carta of small business. We consider it the Magna Carta of agriculture also." Id. at 200.

5 "This bill has the opposition of all cheaters, chiselers, bribe takers, bribe givers, and the greedy who seek monopolistic powers which would destroy opportunity for all young people and which would eventually cause Government ownership, as the people of this country will not tolerate private monopoly.

"The bill has the support of those who believe that competition is the life of trade; that the policy of live and let live is a good one; that it is one of the first duties of Government to protect the weak against the strong and prevent men from injuring one another; that greed should be restrained and the Golden Rule practiced." 80 Cong. Rec. 3447 (1936), set out in Rowe, Price Discrimination Under the RobinsonPatman Act 14 (1962). 
between the effects of the legislation and the elimination of economic discrimination. Three statutory schemes with different political and social origins will therefore be studied; the Robinson-Patman Act, the Interstate Commerce Act's regulation of railroads ${ }^{\mathfrak{6}}$ and state regulation of electric utilities. Two are federal schemes and one is the varying product of the many state legislatures. One is applicable in so-called "unregulated" industries and two in "regulated" industries."

An examination of different modes of enforcement is useful because, as we shall see, the effect of an anti-discrimination statute upon the practice of economic discrimination depends at least as much upon the enforcement agency's interpretation of its role as it does upon the statutory language. Such agencies, in the treatment of legislation primarily designed to eliminate economic discrimination, may interpret it, for example, as intended to insure equal treatment and preserve economic opportunity. ${ }^{8}$ Such a view may be thought of as an "equal opportunity" interpretation. On the other hand, and this may particularly be the case where the prohibition is part of a more comprehensive regulatory scheme, the agencies concerned may apply the proscription only to situations in which purchasers who are to the common mind indisputably equals are treated unequally. Such a restrictive view of the prohibition, which may be called a "promotional" interpretation, may be adopted in order to make the prohibition consistent with the regulatory agency's general policy of promoting consumption of the product or service under regulation.

A comparison of these three divergent approaches to a single phenomenon should also be useful in a number of collateral inquiries. It

6 An analysis of the Interstate Commerce Act seems particularly appropriate in any review of anti-discrimination legislation. We have it on the highest judicial authority that the principal purpose of the act was to eliminate discrimination. See Louisville \& N. R.R. v. United States, 262 U.S. 740, 749-50 (1931); New York v. United States, 331 U.S. 284,296 (1947).

7 Every industry is regulated to a greater or lesser degree. Indeed, it would be difficult to think of an industry where there were not some limitations affecting price or entry-whether, for example, by way of the antitrust laws, fair trade or usury laws or licensing, disclosure, labeling and safety requirements. Nevertheless, it is conventional to distinguish between "regulated" and "unregulated" industries. In general, the former category includes industries where there is comprehensive affirmative regulation, particularly of price levels and structure, whereas the latter category refers to regulation of a less comprehensive nature.

8 The Senate Judiciary Committee announced as its "guiding ideal": "the preservation of equal opportunity to all usefully employed in the service of distribution comportably with their ability and equipment to serve the producing and consuming public with real efficiency, and the preservation to that public of its freedom from threat of monopoly or oppression in obtaining its needs and disposing of its products." S. REP. No. 1502, 74th Cong., 2d Sess. 3 (1936), set out in Rowe, op. cit. supra note 5, at 20. 
should reveal something about the nature of economic discrimination and the problems which necessarily arise in attempting to eliminate it. It should tell us something about the difference in method between comprehensive regulation of certain "regulated" industries by independent regulatory commissions, such as the Interstate Commerce Commission and state utility commissions, as contrasted with the more limited regulation of "unregulated" industries by agencies such as the Federal Trade Commission. More particularly, it may be possible to determine to what extent differences in the overall system of regulation tend to produce different substantive rules governing discrimination.

The inquiry in this paper will be conducted in several stages. First, the nature of economic discrimination will be examined with a view to identifying its indispensable elements. The three statutory schemes in question will then be reviewed in preparation for a comparative analysis of the manner in which three potentially discriminatory practicesquantity discounts, classification of customers and geographical differentials-are regulated under each of the three statutory schemes. The role of the meeting competition defense in any scheme for regulating discrimination will also be considered. Finally, a comparison of the purpose and method in enforcement of the three statutory schemes will be undertaken.

\section{The Nature of Economig Discrimination}

Before proceeding to an analysis of statutes purporting to regulate economic discrimination, it would be useful to arrive at a working definition of the economic phenomenon supposedly under regulation. Rather than arbitrarily setting forth a definition of economic discrimination and then examining what behavior falls within and without that definition, it would seem preferable, at least for a common-law lawyer, to proceed in a somewhat more inductive fashion. ${ }^{\circ} \mathrm{A}$ clear case of economic discrimination will be examined in detail in order to arrive at a general rule for determining what other pricing policies should also constitute economic discrimination.

If a seller sells a single product to different purchasers at different prices (all units having been produced and distributed by him at the same cost), it appears to be generally conceded that the seller has engaged in economic discrimination. The next issue is whether the seller has also engaged in economic discrimination where the price to different purchasers for the same product is the same but the seller's costs are different. To determine whether the latter situation involves economic

9 See generally Levi, AN INTROduction to LEGAL REASONING (1948). 
discrimination, we must determine why it was that in the same-cost situation, the seller chose to sell at different prices.

It should be observed that in a highly competitive market a seller could not sell identical products at different prices because other sellers would concentrate on the high-price sector until such time as the price - in that sector had been driven down to the price in other sectors. For example, the individual wheat farmer has neither the power nor the incentive to discriminate because he can sell his entire product at the market price and not a single bushel at any higher price. ${ }^{10}$ This is not to say that a discriminating seller may not face considerable "competition" in the popular sense but rather only that by one means or another the seller has sufficient economic power to set the price, within certain limits, for his own products in at least the high price sector. ${ }^{11}$

It should be observed further that the two sectors must be effectively separated in some way in order for the seller to be able to maintain differential prices. In the absence of such separation, purchasers in the high price sector would shift their purchases to the low price sector and, assuming the lower price reflects additional competition in that sector, the low price sector sellers would shift their sales to the high price sectors. Many techniques may be utilized to separate two classes of purchasers. For example, the same devices which serve to give the seller a measure of monopoly power, such as trademarks and brand-name advertising, may also serve to separate the market for such trademarked or branded merchandise from the market for identical products not bearing the trademark or brand name.

Assuming then, in order to simplify the analysis, that the seller has a complete monopoly and can separate the high price from the low price sectors, the question is why he will charge purchasers different prices rather than a single "monopoly" price-that is, a single price which will maximize his monopoly profits. A preliminary observation is that the seller will charge differential prices only where there is a difference in the elasticity of demand (that is to say, the extent to which quantity demanded falls as price rises) of purchasers in the various sectors. The seller, rather than quoting a single price, will attempt to set prices which differ according to the quantity demanded. To put the principle in

10 The example ignores the possible effect of federal regulation of wheat growing and marketing on the legal right of the farmer to sell or pledge his wheat at fixed sale or loan prices.

11 Aside from the situation where the natural workings of the market produce a structure with a limited number of sellers, power over price may stem, to take a few examples, from collusion among sellers, from lawful monopolies stemming from patents and from marketing techniques designed to create a series of markets for physically similar products including use of trademarks and brand name advertising. 
somewhat more precise terms, where elasticity of demand differs among sectors, the seller will sell in each sector at that price at which the additions to gross revenues from sale of an additional unit will equal additions to costs with respect to each sector. He will thereby maximize profits with respect to each class. The aggregate monopoly profit thus obtained will necessarily be greater than that which would be obtained through a single price. At any single price there would always remain the opportunity to increase total net profit by increasing or decreasing price to at least one class.

Application of the line of reasoning just set forth also reveals, and this is a point frequently ignored in the enforcement of anti-discrimination statutes, that charging the same price to two purchasers where the seller's costs with respect to each differ must similarly be considered discrimination. ${ }^{12}$ Here again the seller is seeking to maximize monopoly profit based on differences in the elasticity of demand of the purchasers. Where the incremental costs of whatever kind associated with additional sales differ between two sectors (as, for example, where the costs of distribution of an otherwise identical product differ with respect to each sector), competition would result in a price differential between the two sectors equal to the differential in such incremental costs. So long as additions to gross revenues from additional sales to one sector exceeded additions to costs, competitors would concentrate on selling to that sector until, through a reduction in prices to that sector, additions to gross revenues and costs were equal. Similarly, if additions to gross revenues from sales to another class were less than additions to cost, sales to that sector would be discouraged until such time as, through an increase in prices to that sector, additions to gross revenues and costs were equal. The monopolist, free from the constraints of competition and seeking to maximize monopoly profits with respect to each class, will find that the profit maximizing price structure will not always be one at which the differential in price is equal to the differential in incremental costs. To avoid inconveniences in quoting prices and protests of unfairness by customers (as well as avoiding, as we shall see, liability under certain price discrimination statutes such as the RobinsonPatman Act), the monopolist may select uniform prices even though uniform prices might not yield the theoretically maximum total profits.

12 That differential costs and equal prices constitute price discrimination is a point frequently made in the secondary literature, but it is unfortunately rarely if ever explained why that is so. See, e.g., Atr'y GeN. NAt'z Comm. Antrtrust Rep. 333-34 (1955); Edwards, op. cit. supra note 2, at 2; Rowe, op. cit. supra note 5, at 29; Adelman, The Consistency of the Robinson-Patman Act, 6 STAN. L. REv, 3, 4-5 (1953); Adelman, Price Discrimination as Treated in the Attorney General's Report, 104 U. PA. L. Rev. 222, 223 (1954); Adelman, Book Review, 50 AM. EcoN. REv. 790 (1960). 
Thus, where incremental costs differ, uniform prices signal the existence of economic discrimination.

From the foregoing analysis, one may conclude that economic discrimination occurs whenever differentials in price for a single product are not related to differentials in incremental costs. This definition is somewhat ambiguous because its generality masks two technical issues: (1) whether a nondiscriminatory price structure involves price differentials equal or proportional to incremental costs; ${ }^{13}$ and (2) whether the relevant marginal costs are of the short-term or of the long-term variety. ${ }^{14}$ While it cannot be said that either of these issues is unimportant, nevertheless the agencies and courts charged with administering the three statutory schemes in question are so far from comprehending the essential nature of economic discrimination that a discussion of these highly sophisticated sub-issues would not further the present inquiry into the administration of the three statutory schemes under review.

A further, and more substantial, ambiguity lies in the concept of a single product. In many cases, whether or not a given price structure is discriminatory will turn on a determination whether one or two products are involved. ${ }^{15}$ Resolution of this issue in a particular case may be a subtle and uncertain exercise. Any of a number of criteria might be emphasized in reaching a judgment. For example, products may be the same in the sense that the objects themselves are physically identical. On the other hand, one may stress the function to be performed in order to find sameness despite physical differences. Or it may be important whether the two items are turned out by the same production base or are, on the contrary, the end results of different production processes. One may, however, depart entirely from such criteria in order to emphasize the judgment of the market place on the matter. Under this view, products are different which consumers judge to be different. Attention is drawn to trademarks, labels, packaging and similar factors which tend to differentiate products in the public mind. This approach may easily carry one too far because a seller could justify any differential unrelated to marginal costs by a perfunctory change, for example, in labels. Perhaps the principle might be qualified to avoid that danger by

13 The proportionality alternative is chosen hereafter in the text, but that choice is not meant to exclude the alternative of equal margins of price over incremental costs as a permissible definition. Compare Stigler, The Theory of Price 215 (rev. ed. 1952), with Adelman, The Consistency of the Robinson-Patman Act, 6 Stan. L. Rev. 3, 4-5 (1953). See also Adelman, Price Discrimination as Treated in the Attorney General's Report, 104 U. PA. L. Rev. 222, 223 n.6a (1955).

14 See, e.g., Bonbright, Principles of Public Utility Rates 317-36 (1961); Adelman, The Consistency of the Robinson-Patman Act, 6 STAN. L. REv. 3, 22 (1953).

15 See Director, Book Review, 24 U. Chr. L. REv. 606, 608 (1957). 
requiring the seller to show that the difference in label had created in the minds of customers generally a sufficiently concrete belief that different products were involved so that they would be willing to pay a higher price in the case of one label than in the case of the other. The diffculties with such a consumer opinion approach are, however, more fundamental. A rule based on this theory would tend to encourage the type of behavior by sellers which makes possible effective economic discrimination-that is, adoption of techniques designed to differentiate customer demands so that customers in the higher price sector will be unwilling to accept, despite the price differential, the lower price item. These techniques, which tend to make discrimination more effective, should hardly be encouraged by any statute designed to eliminate economic discrimination. While the appropriate resolution of this issue is far from apparent, an approach emphasizing physical characteristics seems preferable. Where services rather than goods are involved, the problem is doubly difficult. Physical characteristics, while perhaps still a possible criterion, are difficult to measure and the function served by the services assumes a higher significance.

One of the most difficult problems in regulating economic discrimination is to determine whether price differentials unrelated to cost differentials constitute economic discrimination where the seller faces greater competition in the low than in the high price sector. Should a price differential be deemed illegal where the seller quoted the lower price merely in order to meet competition from another seller? This approach, recognizing that where sellers' incremental costs do not vary differential pricing arises from differences in buyers' elasticity of demand, would distinguish two types of differential charging: first, where the difference in elasticity of demand arises from differences in purchasers' tastes for and use of the product; and second, where the difference in elasticity of demand arises from differences in the competitive condition of the market (for example, in the number of sellers) in the two sectors. Thus, where the seller had a monopoly in one sector and faced many competitors in another sector, his price in. the first sector would presumably be a higher monopoly price and in the second sector a lower competitive price. No attempt will be made here to resolve the question of the relevance of differing competitive conditions to economic discrimination. The purpose of this paper is not primarily to construct an abstract definition of economic discrimination but rather to examine the techniques used to regulate discrimination. ${ }^{16}$ It should therefore be

16 While economic discrimination is certainly suspect among economists, see DIRLAM \& KAHN, FAIR COMPETITION 202 (1954), the condemnation is far from universal. Economic discrimination may under certain circumstances permit an increase in production and, in declining cost industries, through increased production, lower prices for 
observed that if one adopts the position that differential pricing arising from differences in competitive conditions is not discrimination, it would not be necessary to consider the desirability of a meeting competition defense because such a defense would be superfluous. But if discrimination is defined more broadly, the availability of a meeting competition defense becomes crucial. The question will therefore be examined in the following manner. Following the general review of the three statutory schemes and the regulation of various types of discriminatory practices thereunder, the relevance of competition as a defense will be examined under each of the three schemes.

\section{The Statutes}

\section{A. The Robinson-Patman Act}

The Robinson-Patman Act, ${ }^{17}$ unlike the Interstate Commerce Act and state public utility statutes, is almost exclusively concerned with discrimination. ${ }^{18}$ The core of the act is section 2(a) ${ }^{19}$ which, in general,

all purchasers. In some cases, economic discrimination may permit production of goods which would not be produced at all in the absence of such discrimination. See generally Robinson, The Economics of IMPERFEcT CoMpetrrion 179-208 (1933). And economic discrimination may allow a greater degree of price rivalry between firms in a market with few sellers than would otherwise be likely. See McGee, Price Discrimination and Economic Effects: The Standard Oil of Indiana Case, 23 U. CHI. L. REv. 398 (1956).

Since economic discrimination is possible, however, only where sellers have a measure of monopoly power, it might be thought preferable to deal with that disease directly rather than with mere symptoms like discrimination. But in many industries it may be hopeless to attempt to create enough firms to eliminate the opportunity for discrimination. And there are so strongly entrenched in the economy so many monopolies created by the legal system that their elimination cannot be considered a practicable alternative to regulation of economic discrimination.

It might be proposed that regulatory agencies be empowered, through control over prices, to create artificially the price structure and hence the allocation of resources that would exist under competition. One approach, usually found in the literature on public utilities, is that prices be set equal to marginal costs without regard to so-called fixed costs or to the nature of purchasers' demands. See, e.g., BonBriGHT, op. cit. supra note 14; Coase, The Marginal Cost Controversy, 13 Economica 169 (1946); Vickrey, Some Implications of Marginal Cost Pricing for Public Utilities, 45 As. Econ. REv., ProceEdings 605 (1955). There are grave questions, however, whether such a scheme of mandatory cost pricing can be effectively required by law and efficiently administered by regulatory agencies and whether the resulting direct regulation of prices is desirable in its overall effect.

1738 Stat. 730-31 (1914), I5 U.S.C. $\$ \S 13-13$ (c) (1958).

18 Section 3 of the Robinson-Patman Act goes beyond an anti-discrimination statute insofar as it prohibits, inter alia, selling or contracting to sell goods "at unreasonably low prices for the purpose of destroying competition or eliminating a competitor." For a comprehensive discussion of this provision, see RowE, op. cit. supra note 5, at 452-75; see also United States v. National Dairy Prod. Corp., 372 U.S. 29 (1963).

19 "(a) It shall be unlawful for any person engaged in commerce, in the course of 
makes it unlawful "to discriminate in price between different purchasers of commodities of like grade and quality." The key concept, "to discriminate in price," has been construed to refer simply to the charging of different prices. ${ }^{20} \mathrm{~A}$ prima-facie case is made out by establishing that a seller has, with respect to "commodities of like grade and quality,"

such commerce, either directly or indirectly, to discriminate in price between different purchasers of commodities of like grade and quality where either or any of the purchases involved in such discrimination are in commerce, where such commodities are sold for use, consumption, or resale within the United States or any Territory thereof or the District of Columbia or any insular possession or other place under the jurisdiction of the United States, and where the effect of such discrimination may be substantially to lessen competition or tend to create a monopoly in any line of commerce, or to injure, destroy, or prevent competition with any person who either grants or knowingly receives the benefit of such discrimination, or with customers of either of them: Provided, That nothing herein contained shall prevent differentials which make only due allowance for differences in the cost of manufacture, sale, or delivery resulting from the differing methods or quantities in which such commodities are to such purchasers sold or delivered: Provided, however, That the Federal Trade Commission may, after due investigation and hearing to all interested parties, fix and establish quantity limits, and revise the same as it finds necessary, as to particular commodities or classes of commodities, where it finds that available purchasers in greater quantities are so few as to render differentials on account thereof unjustly discriminatory or promotive of monopoly in any line of commerce; and the foregoing shall then not be construed to permit differentials based on differences in quantities greater than those so fixed and established: And protided further, That nothing herein contained shall prevent persons engaged in selling goods, wares, or merchandise in commerce from selecting their own customers in bona fide transactions and not in restraint of trade: And provided further, That nothing herein contained shall prevent price changes from time to time where in response to changing conditions affecting the market for or the marketability of the goods concerned, such as but not limited to actual or imminent deterioration of perishable goods, obsolescence of seasonal goods, distress sales under court process, or sales in good faith in discontinuance of business in the goods concerned.

"(b) Upon proof being made, at any hearing on a complaint under this section, that there has been discrimination in price or services or facilities furnished, the burden of rebutting the prima-facie case thus made by showing justification shall be upon the person charged with a violation of this section, and unless justification shall be affrmatively shown, the Commission is authorized to issue an order terminating the discrimination: Provided, however, That nothing herein contained shall prevent a seller rebutting the prima-facie case thus made by showing that his lower price or the furnishing of services or facilities to any purchaser or purchasers was made in good faith to meet an equally low price of a competitor, or the services or facilities furnished by a competitor."

20 Section 2(c), the "brokerage" provision, makes it unlawful "to pay or grant, or receive or accept, anything of value as a commission, brokerage or other compensation, or any allowance or discount in lieu thereof, except for services rendered" under certain circumstances and with certain exceptions. For a comprehensive discussion of this provision, see Rowe, op. cit. supra note 5, at 330-62 (1962). Sections 2(d) and 2(e) govern the legality of promotional payments, facilities and services. See id. at 363-420. Since these subsections do not purport, strictly speaking, to regulate price discrimination, they will not be discussed here. 
charged two purchasers different prices and that competitive injury has resulted.21 Such a prima-facie case can be defeated by a showing that, under the proviso to section 2(a), the differential made "only due allowance for differences in the cost of manufacture, sale or delivery resulting from the differing method or quantities in which such commodities are ... sold or delivered" or that, under section 2(b), the lower price "was made in good faith to meet an equally low price of a competitor."

1. Price Differential. The first element of a price discrimination charge under the Robinson-Patman Act is, as the foregoing discussion suggests, the existence of a price differential. A corollary of the principle that discrimination under the act involves the charging of different prices is that a seller cannot be held to have discriminated in price under section 2(a) where he charges the same price to different purchasers even though the costs involved in the two sales are different. ${ }^{22}$ This rule is completely at odds with the economic notion of discrimination which, as we have seen, refers to the charging of prices not proportional to costs. $^{23}$

2. Competitive Injury. The second element of a prima-facie case under section 2(a) is competitive injury. It is illegal "to discriminate in price" only where "the effect of such discrimination may be substantially to lessen competition or tend to create a monopoly in any line of commerce, or to injure, destroy or prevent competition with any person who either

21 FTG v. Anheuser-Busch, Inc., 363 U.S. 536, 548-49 (1960).

22 Sano Petroleum Corp. v. American Oil Co., 187 F. Supp. 345, 353-54 (S.D.N.Y. 1960). See also Klein v. Lionel Corp., 138 F. Supp. 560, 565 (D. Del. 1956), aff'd, 237 F.2d 13 (3d Cir. 1956); FTC v. A.E. Staley Mfg. Co., 324 U.S. 746, 757 (1945). But see FTC v. Standard Brands, 189 F.2d 510 (2d Cir. 1951); Samuel H. Moss v. FTC, 148 F.2d 378 (2d Cir. 1945); setting forth the Second Circuit view that upon proof of a price differential the burden of proof on competitive injury shifts to the defendant seller. Consult Rowe, op. cit. supra note 5, at 99-100.

23 See Note 12 and pages 6-7 supra. This anomalous effect of a purportedly antidiscriminatory statute is occasionally observed by commentators but seldom defended. Professor Corwin Edwards, however, argues: "[T] reflected in a price difference would be inappropriate, although buyers should have an incentive to promote efficiency because they receive lower prices by doing so, sellers, too, should have an incentive to adopt efficient methods because they might be able to retain the gains derived therefrom. The appropriate statutory standard as to the relation between price and cost is one in which cost advantage may be, but need not be, passed on to the buyer." Edwards, The Price Discrimination Law 615 (1959).

The difficulty with that view is that the seller always profits by discriminating for otherwise he would not seek to discriminate. If the purpose of an anti-discrimination law is to preclude discrimination, and not merely to provide economic security to small distributors under a "fairness" theory, surely all forms of economic discrimination ought to be equally proscribed. 
grants or knowingly receives the benefits of such discrimination, or with customers of either of them." Three principal categories of injury have been distinguished: (1) Injury to competition among the seller and his competitors (primary-line injury); (2) injury to competition among the favored purchaser and his competitors (secondary-line injury); and (3) injury to competition among the customers of the favored buyers and those customers' competitors (tertiary-line injury). ${ }^{24}$

It is doubtful that tertiary-line injury will support a section 2(a) violation except perhaps in rather unusual circumstances, but either primary or secondary-line injury will clearly suffice. A decisive difference between the latter two types of injury is that the courts have required far more derangement of the market at the primary line than at the secondary line. Thus, in FTC v. Morton Salt Co., the Supreme Court adopted the rather expansive view that the requisite injury to competition at the purchasers' level could be established by demonstrating an "injury to the competition victimized by the discrimination" and that no specific evidence of injury, beyond the fact of substantial difference in price on sales to the favored and disfavored purchasers, was necessary to prove "what would appear to be obvious, that the competitive opportunities of certain merchants were injured when they had to pay ... substantially more for their goods than their competitors had to pay." 25 In spite of the breadth of the Court's language, counsel supporting a complaint in FTC proceedings continue to offer independent evidence of injury at the secondary level (such as the loss of business by, or impairment of the profits of, disfavored customers). ${ }^{26}$ It is nonetheless clear that a substantially higher standard of proof is required in a primary-line than in a secondary-line case. In Anheuser-Busch, Inc. v. FTC27 the Seventh Circuit held that injury to a competitor as opposed to injury to competi-

24 Tertiary-line injury might arise where a manufacturer-seller, selling to both wholesalers and retailers, sells to the former at a price so much lower than to the latter that the wholesaler can sell to other retailers at less than the manufacturer's price to retailers. See generally RowE, op. cit. supra note 5, at 205. But, of course, the direct buying retailer may choose in such a case to buy from the wholesaler thereby limiting any injury.

25334 U.S. 37, 49, 50 (1948). The test, according to Justice Black writing for the Court, was whether there was a "reasonable possibility" (rather than a probability or likelihood) that the price differential would have the specified effects.

26 See United Biscuit Co., No. 7817, FTC, June 28, 1962; Tri-Valley Packing Ass'n, Nos. 7225, 7496, FTC, May 10, 1962; cf. Fred Bronner Corp., 57 F.T.C. 766 (1960). Testimony by the nonfavored purchasers that they were not in fact injured has been insufficient to overcome the inference of injury arising from a substantial difference in price. E. Edelmann \& Co. v. FTC, 239 F.2d 152 (7th Cir. 1956); Moog Indus., Inc. v. FTC, 238 F.2d 43 (8th Cir. 1956). That independent evidence of injury may be required where the differentials are sporadic rather than systematic is suggested by American Oil Co., No. 8183, FTC, June 27, 1962.

27289 F.2d 835 (7th Cir. 1961). 
tion was not sufficient to establish requisite primary-line injury. Section 2(a), said the court "is not concerned with mere shifts of business between competitors" but rather "with substantial impairment of the vigor or health of the contest for business, regardless of which competitor wins or loses." 28 Because the standard for secondary-line injury is so much easier to meet, the FTC usually attempts to establish primary-line injury only in cases where no substantial competition exists between the favored and disfavored purchasers.

3. Cost Justification. Even though a differential in price between purchasers may injure competition in the statutory sense, the differential is not unlawful where the defendant establishes that the differential makes "only due allowance for differentials in the cost of manufacture, sale or delivery resulting from the differing methods or quantities in which such commodities are to such purchasers sold."29 Thus, the Robinson-Patman Act reflects legislative awareness that differentials in price which merely reflect differentials in cost should not be proscribed as discriminatory.

The cost justification defense may not be adequate to offset the basic tendency of the act, particularly as administered, to require price uniformity and thereby to promote economic discrimination. First, the burden of proof is placed upon the defendant to establish the defense. Second, such a high degree of specificity and completeness of evidence is required that the normal accounting records maintained by a business enterprise will seldom suffice to establish the defense. ${ }^{30}$ In reviewing the FTC's requirements the Supreme Court observed that "the Commission

$28 I d$. at 840, on remand from FTG v. Anheuser-Busch Inc., 363 U.S. 536 (1960). See also Atlas Bldg. Prod. Co. v. Diamond Block \& Gravel Co., 269 F.2d 950, 954-55 (10th Cir. 1959). The Seventh Circuit did suggest, however, that in geographical discrimination cases, proof of predatory intent (buccaneering) might substitute for proof of substantial injury to competitors. 289 F.2d at 843. See Pure Oil Co., No. 6640, FTC, Sept. 28, 1962; see also Atlas Bldg. Prod. Co. v. Diamond Block \&: Gravel Co., 269 F.2d 950 (10th Cir. 1959), for the proposition that the seller's size, economic power and comparative prices may be considered in determining the effect on primary-line injury. It must be recognized, however, that the Anheuser-Busch decision was a defeat for the position, asserted from time to time by the FTC, under which competitive primary-line injury could be made out by a showing that business had been diverted from a competing seller, whether or not there had been any deterioration in the quality of competition at the seller level. See, e.g., Minneapolis-Honeywell Regulator Co., 44 F.T.C. 351 (1948), rev'd, 191 F.2d 786 (7th Cir. 1951), cert. denied, 344 U.S. 206 (1952); Samuel H. Moss, Inc., 36 F.T.C. 640 (1943), aff'd, 148 F.2d 378 (2d Cir. 1945), modified, I55 F.2d 1016 (2d Cir. 1946). Indeed, there is some question whether the FTC is prepared to accept the Anheuser-Busch doctrine in full. See Forster Mfg. Co., No. 7207, FTC, March 18, 1963.

2949 Stat. 1526 (1936), 15 U.S.C. § 13(a) (1958).

30 See Sawyer, Cost Justification of Quantity Differentials, 1 ANrrrrusr BurL. 573, $578-80$ (1956). 
has not been content with accounting estimates; a study seems to be required, involving perhaps stopwatch studies, numerical counts of invoices or bills and in some instances of the number of items or entries on such records, or other such quantitative measurement . . ."31 Finally, it is not sufficient to establish that the costs in question differ substantially; the FTC seems to require that the price differential be justified to very nearly the last sou ${ }^{32}$ by concrete, specific quantitative data. As a consequence of these restrictive standards, cost justification defenses have been exceedingly difficult to establish. The Attorney General's National Committee to Study the Antitrust Laws may not have gone too far in concluding that the defense "has proved largely illusory in practice." ${ }^{3}$ The effect of these rigorous requirements is to induce sellers to reflect less than the full extent of cost differentials in prices charged and hence to engage in conduct which can only be classified as economic discrimination. ${ }^{34}$

The availability of the cost justification defense is modified, moreover, by the power of the FTG, set forth in the second proviso to section 2(a), to "fix and establish quantity limits ... as to particular commodities or classes of commodities, where it finds that available purchasers in greater quantities are so few as to render differentials on account thereof unjustly discriminatory or promotive of monopoly in any line of commerce." Where the quantity limits power of the FTC is invoked, cost is totally disregarded and economic discrimination must result. ${ }^{35}$

\section{B. The Interstate Commerce Act}

In turning from the Robinson-Patman Act to the Interstate Commerce Act, ${ }^{36}$ one is immediately struck by the difference in terminology used in discussing problems of discrimination. It is traditional under

31 Automatic Canteen Co. v. FTC, 346 U.S. 61, 68 (1953); see Borden Co., No. 7129, FTC, Nov. 28, 1962.

32 See Thompson Prod., Inc., 55 F.T.C. 1252 (1959).

33 AtT'y. Gen. NAT'L Comm. Antrtrust Rer. 171 (1955).

34 See Adelman, The Consistency of the Robinson-Patman Act, 6 Stan. L. Rev. 3, 7-14 (1953).

35 The quantity-limits provision, while showing a high disregard of the drafters for the nature of economic discrimination, is not particularly significant in the enforcement of the act in view of the FTC's reluctance to call on its statutory power. Quantity limits have been imposed in only a single proceeding, but the order, directed at automotive replacement tires and tubes, was set aside by a district court. B.F. Goodrich Co. v. FTC, 134 F. Supp. 39 (D.D.C. 1955), aff'd, 242 F.2d 31 (D.C. Cir. 1957). See, for a general discussion of the proviso, ATT'y. GEN. NAT'L COMM. ANTrTRUST REP. 17677 (1955); Edwards, The Price Discrimination Law 271-85 (1959); Rowe, op. cit. supra note 5 , at $312-20$.

3624 Stat. $379-87$ (1887), 49 U.S.C. §§ 1-27 (1958). 
the latter statute to distinguish three types of discrimination-personal discrimination, discrimination among commodities and discrimination among localities. Personal discrimination refers to discrimination among shippers of like commodities between the same points of origin and destination. Discrimination among commodities refers to discrimination among shippers based upon differences in the kinds of commodities shipped by each. Discrimination among localities involves discrimination among shippers engaged in the shipment of like commodities where the shipments in question are from different points of origin or to different points of destination.

The Interstate Commerce Act contains general provisions forbidding discrimination which are not fundamentally different from the RobinsonPatman Act's proscriptions. Directed primarily at personal discrimination, Section 2 of the Interstate Commerce Act prohibits, under the rubric of "unjust discrimination," the charging of "a greater or less compensation" to one shipper than another with respect to "a like kind of traffic under substantially similar circumstances and conditions." 37 Section 3 also reaches personal discrimination but is more significant for its proscription of discrimination among commodities and among localities. It prohibits both "any undue or unreasonable preference or advantage" to any shipper and subjection of any shipper to "any undue or unreasonable prejudices or disadvantages in any respect whatsoever." 38 Section 4, the long-and-Short-Haul clause, is directed against a very particular form of discrimination among localities-charging more for a short haul than for a long haul over the same line in the same direction, the shorter being included within the longer. ${ }^{39}$

37 "[It shall be unlawful for] any common carrier . . directly or indirectly, by any special rate, rebate, drawback, or other device, [to] charge, demand, collect, or receive from any person or persons a greater or less compensation for any service rendered, or to be rendered, in the transportation of passengers or property ... than it charges, demands, collects or receives from any other person or persons for doing for him or them a like or contemporaneous service in the transportation of a like kind of traffic under substantially similar circumstances and conditions . . . 24 Stat. 379-80 (1887), 49 U.S.C. \& 2 (1958).

38 "It shall be unlawful for any common carrier... to make or give undue or unreasonable preference or advantage to any particular person, company, firm, corporation, association, locality, port, port district, gateway transit point, region, district, territory, or any particular description of traffic, in any respect whatsoever." 49 Stat. 107 (1935), 49 U.S.C. § 3(1) (1958). Section 3(4) prohibits a specific kind of discrimination; carriers are forbidden to "discriminate in their rates, fares, and charges between connecting lines, or unduly prejudice any connecting line in the distribution of traffic that is not specifically routed by the shipper." See Dixie Carriers v. United States, 351 U.S. 56 (1956); ICC v. Mechling Barge Line, 330 U.S. 567 (1947); Arrow Transp. Co. v. United States, 176 F. Supp. 411 (N.D. Ala. 1959), aff'd per curiam, 361 U.S. 353 (1960).

39 "It shall be unlawful for any common carrier ... to charge or receive any 
If the statutory basis for regulation of discrimination by railroads had been limited to the foregoing sections, a development of the law on a case-by-case basis leading to a legal scheme not unlike that under the Robinson-Patman Act might have been anticipated. There are, however, a number of crucial differences between the regulation imposed by the Interstate Commerce Act and that imposed by the Robinson-Patman Act. First, as in the case with most industries classified as regulated, the Interstate Commerce Act gives the ICC power to regulate the general level of rates. Thus, the ICC may regulate the overall level of rates of carriers in order to assure that such rates are "just and reasonable." 40 In general, the purpose of rate-level regulation is to assure that the railroads' return on invested capital is not excessive.

Second, the ICG has the power, quite aside from its power to regulate discriminatory rates, to regulate individual rates to assure that they are "just and reasonable." 41 Because this power extends to determining minimum, as well as maximum, individual rates, the Commission may, and often does, use this power in lieu of its statutory powers over discrimination. For example, minimum rate regulation is most important in cases where railroads reduce specific rates in response to competition from truck or barge lines, a situation which would normally also give rise to a geographical discrimination problem. ${ }^{42}$ While the portion of

greater compensation in the aggregate for the transportation of passengers, or of like kind of property, for a shorter than for a longer distance over the same line or route in the same direction, the shorter being included within the longer distance, or to charge any greater compensation as a through route than the aggregate of the intermediate rates ... Provided, That upon application to the Commission and after investigation, such carrier, in special cases, may be authorized by the Commission to charge less for longer than for shorter distances for the transportation of passengers or property and the Commission may from time to time prescribe the extent to which such designated carriers may be relieved from the operation of this section ...." 54 Stat. 904 (1940), 49 U.S.C. § $4(1)$ (1958).

4024 Stat. 379, 384, (1887), 41 Stat. 488, (1920), as amended, 49 U.S.C. $\S \S 1,15$, 15(a) (1958). For a general discussion of rate level regulation, see LockLIN, Economrcs of Transportation 332-429 (4th ed. 1954); Sharfman, The Interstate Commerce Commission, pt. III, vol. B, pp. 1-308 (1936).

4124 Stat. 379, 384 (1887), 49 U.S.C. \& 1, 15 (1958). For a general discussion of regulation of individual rates, see LockLIN, op. cit. supra note 40, at 430-78.

42 In 1958 Section $15 \mathrm{a}(3)$ was added to the act to guide the Commission in minimum rate cases involving intermodal competition. While prior to the amendment the Commission had been charged to "consider the facts and circumstances attending the movement of the traffic by the carrier or carriers to which the rate is applicable," the 1958 amendment puts it on notice that "rates of a carrier shall not be held up to a particular level to protect the traffic of any other mode of transportation, giving due consideration to the objectives of the national transportation policy . . . "While it is generally agreed that the purpose of the 1958 amendment was to give the railroads more freedom to lower individual rates to meet truck and barge competition, 
the paper devoted to the ICC deals only with discrimination problems which are treated as such by the ICC, an exhaustive treatment of railroad discrimination would involve a full scale analysis of the ICC's minimum rate powers and their relation to intermode competition. ${ }^{43}$

The third, and perhaps most significant, difference between the regulated and unregulated sectors of the United States economy lies in the almost universal requirement, where rates are subject to regulation, that all rates be filed with a regulatory agency before becoming effective. In the case of railroads Section 6 of the Interstate Commerce Act requires that railroads "file with the Commission ... and print and keep open to public inspection schedules showing all the rates, fares, and charges," that no change should be made except upon thirty days notice and that the railroads refrain from departing from the filed rate for any purpose. ${ }^{44}$ Section 6 as originally enacted did not prove fully effective in preventing departures from published rates by covert methods such as rebates, underbilling and false classification. This weakness in the original act was remedied in the Elkins Act of $1903^{45}$ which prohibited enjoyment of the fruits of personal discrimination by the favored shipper as well as by providing more effective penalties against carriers for departures from published rates. Under the Elkins Act, a shipper "who shall knowingly ... directly or indirectly, by or through any means or device whatsoever, receive or accept from a common carrier any sum of money or any other valuable consideration as a rebate or offset against the regular charges for transportation of such property, as fixed by the

there is considerable dispute about the exact meaning of the new statutory language, particularly its reference to the national transportation policy, and the Commission's interpretation appears to have varied from time to time.

43 The literature on intermode competition and the minimum-rate power is extensive and growing at a rapid rate. Among recent comments, see, e.g., Friendly, The Federal Administrative Agencies 106-40 (1962); Fulda, Competition in the Regulated Industries: Transportation 339-74 (1961); Williams, The Regulation of RailMotor RATE Competrtion (1958); Report by the Special Study Group on Transportation Policies in the United States of the Committee on Commerce, S. REP. No. 445, 87th Cong., 1st Sess., pp. 385-444 (1961) [hereinafter cited as the Doyle Report]; Comment, 73 Harv. L. REv. 762 (1960); and many articles in recent volumes of the I.C.C. Practitioner's Journal.

4424 Stat. 380 (1887), as amended, 49 U.S.C. $\S 6$ (1958). Section 6 has been so scrupulously enforced that it has been held that even where the filed rate is clearly erroneous and manifestly inadequate to compensate the railroad, the filed rate must be followed. Armour \& Co. v. Atchison, T. \& S.F. Ry., 254 F.2d 719 (7th Cir. 1958); Tobin Packing Co. v. Baltimore \& O. R.R., 299 I.C.C. 221 (1956); Ryan Co. v. Missouri Pac. R.R., 177 I.C.C. 348 (1931).

4532 Stat. 847 (1903), 49 U.S.C. $\S 41$ (1958). For a description of the weaknesses of the enforcement machinery of the original Interstate Commerce Act sought to be remedied by the Elkins Act, see Locklin, Economics of Transportation 212-13 (5th ed. 1960). 
schedule of rates" 46 is liable to pay the government three times the consideration received by the carrier. Because rates must be published, most examples of personal discriminations today involve either covert departures from published rates or the transfer of money or property to the shipper as part of a collateral transaction. ${ }^{47}$ Thus, the opportunities for secret differential pricing are almost totally eliminated.

Fourth, while in the unregulated sector agreement on prices among competitors constitutes a per se violation of Section 1 of the Sherman Act, ${ }^{48}$ such agreements among competing railroads are not only lawful under the Interstate Commerce Act but where arrived at by rate bureaus approved by the ICC, such agreements are specifically insulated from attack under the antitrust laws by the 1948 Reed-Bulwinkle amendment to the Interstate Commerce Act. ${ }^{49}$ This amendment, which confirmed the existing railroad practice of collectively determining rates through rate bureaus, tends to insulate systematic discrimination from the inevitable attrition which would be produced by competition among railroads in the setting of rates. ${ }^{50}$

4634 Stat. 587 (1906), 49 U.S.C. $\$ 41(3)$ (1958). The Hepburn Act of 1906, 34 Stat. 584 (1906), has several provisions directly aimed at personal discrimination. The most important, the "commodities clause," prohibits a railroad from transporting commodities manufactured, mined or produced by it or in which it has an interest (other than timber and commodities intended for its use in the conduct of its business as a common carrier). 34 Stat. 585 (1906), 49 U.S.C. $\S 1(8)$ (1958). The purpose of the clause was to deny railroads owning coal mines an advantage they purportedly had over other owners of coal mines. The theory was that such railroads, having a monopoly of transportation from the coal field, could gain an added advantage for their coal mine by charging high rates for carriage of competitors' coal. Under this theory such competitors would be injured, even though the same rates were charged for carriage from the railroads' mines, for that would be "simply taking money from one pocket and transferring it to the other." See LockLIN, op. cit. supra note 45, at 216. For an analysis and criticism of this theory, see Bork, Vertical Integration and the Sherman Act, 22 U. CHI. L. REv. 157, 194-201 (1954).

47 The most obvious form of departure from a published tariff is the rebate, a remission to the shipper of a portion of the published rate. Such rebates violate both Section 2 of the Interstate Commerce Act and the Elkins Act, however indirectly the rebate may reach the shipper. Union Pac. Ry. v. United States, 313 U.S. 450 (1941). But the duty to adhere to published tariffs can also be breached by providing more service than the tariff requires. While discrimination normally results from such additional service, the essence of the violation of the Elkins Act is the departure from the tariff and thus it is irrelevant that no competitive injury results.

48 Kiefer-Stewart Co. v. Seagram \& Sons, Inc., 340 U.S. 211 (1951). See also United States v. Socony-Vacuum Oil Co., 310 U.S. 150, 223 (1940); Comment, The Per Se Illegality of Price-Fixing-Same Power, Purpose or Effect, 19 U. CH. L. REv. 837 (1952).

4962 Stat. 472 (1948), 49 U.S.C. § 5(b) (1958); see FuLdA, Competrtion IN THE RegULATED INDUSTRIES-TRANSPORTATION 283-309 (1961). The act was a legislative response to the initiative of the commencement of a Sherman Act action by the Department of Justice against the rate-bureau activities of a group of midwestern railroads in a federal district court in Nebraska. See Georgia v. Pennsylvania, 324 U.S. 439 (1945).

50 The only significant restrictions are that the resulting agreements must preserve 


\section{State Utilities Legislation}

State statutes regulating electric utilities have widely differing provisions governing discrimination. ${ }^{51}$ Quite general terms such as "discrimination," "prejudice," "preference" and "disadvantage" are used to describe the proscribed activity. ${ }^{52}$ Qualifying words such as "unjust," "undue" and "unreasonable" are frequently used.53 Typically neither costs nor competition are mentioned in the statute and if cost justification and meeting competition defenses are to be recognized, they must be read into the more general statutory terms. Many statutes do not specifically mention discrimination but the duty to refrain from discrimination is inferred either from the general power of the local commission to regulate rates or from the common-law duty of a public utility to serve all without discrimination.

In considering regulation of discrimination by electric utilities, it is important to note certain features of state regulation which significantly affect both the character of this discrimination and the regulation imposed by the state commissions. For example, rates and rate changes must normally be filed and departures from filed rates are prohibited; thus, rate differentials are on public record for all to see and secret rate cutting is illegal.54 Further, such statutes typically restrict entry so that, except occasionally where a municipal utility provides competition for a regional private utility system or at the border between the service areas of two utilities, a single firm has a legal monopoly over the business of providing electric service. ${ }^{55}$ Even where entry is not limited, the

each carrier's right of independent action and receive ICC approval. For an example of the content of such a rate bureau agreement and the ICC's attitude, see Western Traffic Association-Agreement, 276 I.C.C. 183 (1949).

51 The conventional state method of regulating electric utilities is through a state public service commission. According to responses to a 1960 Federal Power Commission inquiry, only six states did not have such commissions. In some of those "six states electric utilities were regulated in other ways. FPC, STATE Cominission JURIsdiction and Regulation of Electric and Gas Utrlitirs 2-3 (1960). On regulation of electric utilities, see generally Hale \&. Hale, Competition or Control V: Production and Distribution of Electric Energy, 110 U. PA. L. REv. 57 (1961).

52 See, e.g., ARIz. Rev. Stat. Ann. $\$$ 40-334 (1956); 26 Der. Code § 161 (1953); N.H. Rev. Stat. AnN. 378:10 (1955); N.J. Stat. ANN. 48:3-1 (1940); 66 Pa. Stat. § 1144 (1957). But see, e.g., IND. ANN. STAT. \$\$ 54-702 (1951); Mтсн. STAт. ANN. §§ 22-157 (1937).

53 See, e.g., 26 DeL. Code \$ 161 (1953); INd. ANn. STAT. \$ 54-702 (1951); N.H. Rev. Stat. Ann. 378:10 (1955); N.J. Stat. Ann. 48:3-1 (1940); 66 Pa. Stat. § 1144 (1959).

54 "All State commissions with power to regulate rates of electric and gas utilities have the power ... to require prior authorization of rate changes and to suspend proposed rate changes, and to initiate rate investigations of privately owned electric and gas utilities. ..." FPC, op. cit. supra note 51, at 3; see WVELCH, Cases on Public UTILITY REGULATION $491-98$ (1961).

55 "The areas in which electric or gas utilities operate are generally controlled by 
economies of scale may be such that it would be difficult for two electric companies to coexist in the same territory. ${ }^{56}$ Because of this monopoly element, regulation of maximum rate levels and maximum individual rates is common. 57 Where regulation of rate structures extends to both maximum and minimum individual rates, an alternative statutory mechanism is available for dealing with discrimination problems. While individual rates are sometimes set aside as below cost, ${ }^{58}$ there does not appear to be any substantial use of the minimum rate power, used by the ICC to shield barge and truck lines from rail competition, to protect competing sources of energy.

\section{QUANTITY Discounts}

The first specific pricing practice which warrants comparative examination is the quantity discount. The question, with respect to each of the three forms of regulation under scrutiny, is under what circumstances a seller may justify charging one purchaser a lower per-unit price than another purchaser on the ground that the former purchases a larger quantity than the latter.

\section{A. Robinson-Patman Act}

Quantity discounts are governed by the general provisions of Sections 2(a) and 2(b) of the Robinson-Patman Act. Thus, the per-unit price differential inherent in a quantity discount is unlawful where competitive injury results unless the seller establishes that the price differential is cost justified or that the lower quantity price is offered to meet an equally low quantity price of a competitor. An examination of each of these three factors-competitive injury, cost justification and meeting competition-reveals that the act, while in the abstract preserving the seller's right to quote quantity discounts in certain situations, tends in general to discourage such discounts. Except in the unusual case where favored and disfavored purchasers do not compete with each other, the requisite injury to competition at the secondary level is usually rather easy for the FTC to establish, particularly where the purchasers compete in the resale of the products in question. Thus, in FTG $v$. Morton Salt

certificates of convenience and necessity issued by regulatory commissions having jurisdiction .... Franchises and permits from municipalities or other local authorities are, also, generally required in these States and in States not issuing certificates." FPC, op. cit. supra note 51, at 5. See also Twentueth Century Fund, Electric Power and Government Policy 338 n.l (1948); Hale \& Hale, supra note 51; Knier, Competitive Operation of Municipally and Privately Owned Utilities, 47 Mrch. L. Rev. 639 (1949).

56 See Troxel, Economics of Public Utiltries 25-37 (1947).

57 See Hale \& Hale, supra note 51 , at $68-70$, and authorities cited therein.

58 E.g., Re Kaukana Elec. \& Water Dep'ts, 1929E P.U.R. 491 (Wis. R.R. Comm'n 1929). 
Co., ${ }^{50}$ the Supreme Court indicated that where favored and disfavored purchasers resell in competition with each other, the requisite competitive injury may be inferred from the fact of a substantial price differential. ${ }^{60}$ While the cost justification defense saves some discounts based on quantity per shipment, volume discounts based on purchases during a given time period can rarely be cost justified. ${ }^{61}$ And since the meeting competition defense is limited to individual reductions in price designed to meet the equally low price of a competitor, that defense will seldom justify the systematic differentials inherent in a quantity discount system. ${ }^{62}$

The Robinson-Patman Act's hostility to quantity discounts extends well beyond that necessary to eliminate economic discrimination. ${ }^{63}$ The act fails to require quantity discounts in situations where the sale of a larger quantity to one purchaser results in lower unit costs to the seller on sales to that purchaser than to purchasers of smaller quantities.64 The act thereby fails to proscribe one important instance of economic discrimination. More significantly, formidable restrictions on the cost justification defense encourage sellers to engage in economic discrimination, at least to the extent of not reflecting fully in quantity discounts

59334 U.S. 37,47 (1948).

60 Where the purchasers are manufacturers rather than resellers and the differentially priced commodity is only one item in the cost of the purchaser's manufactured product, the Morton Salt rule would seem inapplicable and independent evidence would have to be introduced to establish the requisite injury to secondaryline competition. See Minneapolis-Honeywell Regulator Co. v. FTC, 191 F.2d 786 (7th Cir. 1951). Perhaps Minneapolis-Honeywell stands only for the proposition that the defendant is permitted in such a situation to offer independent evidence to rebut any presumption arising from proof of a substantial price difference.

61 Standard Motor Prod., Inc. v. FTC, 265 F.2d 674 (2d Cir. 1959); P. Sorenson Mfg. Co. v. FTC, 246 F.2d 687 (D.C. Cir. 1957); P. \& D. Mfg. Co. v. FTC, 245 F.2d 281 (7th Cir. 1957); G. E. Niehoff \& Co. v. FTC, 241 F.2d 37 (7th Cir. 1957), modified, Moog Indus., Inc. v. FTC, 355 U.S. 411 (1958); Whitaker Cable Corp. v. FTC, 239 F.2d 253 (7th Cir. 1956); E. Edelmann \& Co. v. FTC, 239 F.2d 152 (7th Cir. 1956); Moog Indus., Inc. v. FTC, 238 F.2d 43 (8th Cir. 1956), aff'd, 355 U.S. 411 (1958); American Can Co. v. Bruce's Juices, Inc., 187 F.2d 919, upheld on rehearing, 190 F.2d 73 (5th Cir. 1951); see H.C. Brill Co., 26 F.T.C. 666, 678 (1938); cf. United States v. Borden Co., 370 U.S. 460 (1962); Mid-South Distrib. v. FTC, 287 F.2d 512 (5th Cir. 1961); American Motor Specialties Co. v. FTC, 278 F.2d 225 (2d Cir. 1960). But cf. American Can Co. v. Russellville Canning Co., 191 F.2d 38 (8th Cir. 1951).

62 See discussion at pp. $49-50$ infra.

63 It might be argued, however, that the FTC's emphasis in its enforcement policy on volume discounts based on quantities purchased over a prescribed period rather than discounts based on quantities purchased in a single transaction indicates that the Commission is sensitive to cost factors. The former kind of discounts are less likely to reflect cost savings. See Edwards, The Price Discrimination Law 208-10 (1959), and cases cited in note 61, supra.

64 See Sano Petroleum Corp. v. American Oil Co., 87 F. Supp. 345, 353 E.D.N.Y. 1960). 
the cost savings of quantity sales. While the substantive rule is that quantity discounts are lawful where cost justified, the act places the burden of proving cost justification on the seller, a burden which, as we have seen, involves a very high standard of proof. ${ }^{65}$

The Robinson-Patman Act's hostility to quantity discounts, even where no economic discrimination is involved, is highlighted by the quantity limits provision. Where only a few purchasers buy in large quantities, the FTG in a quantity limits proceeding may prohibit quantity discounts even though the differential in costs clearly would support a differential in price in a conventional section 2(a) price discrimination proceeding and economic discrimination could thus be avoided only by requiring such quantity discounts. For those who believe that the proof of the pudding is in the eating, it may be well however to observe that the quantity limits proviso has been invoked by the FTC only once and in that case the reviewing court set aside the FTC order, albeit on rather narrow technical grounds. 66

\section{B. Interstate Commerce Act}

The Interstate Commerce Act goes even further than the RobinsonPatman Act in discouraging quantity discounts. Until 1939 the ICC uniformly held all quantity discounts unlawful, except for the quantity discounts inherent in the pervasive distinction between carload and lessthan-carload (LCL) shipments. ${ }^{67}$ Higher rates on LCL than on carload shipments were condoned from the very beginning of ICC regulation on the theory that the shipments were made under dissimilar "circumstances and conditions" within the meaning of section 2.68 The breadth of the differential, however, does not appear to be subjected to scrutiny under the "unjust discrimination" provisions of section 2.69 It would appear

65 "[O]nly the most prosperous and patient business firm could afford pursuit of [this] often illusory defense. Pressure builds to gain legal safety by withholding price differentials from more efficient buyers, thus denying to the public the benefit of mass production and economical distribution processes which Congress intended to preserve ... A" Atr'y. Gen. Nat'c Comm. Antrtrust Rep. 173 (1955). See discussion of the difficulties of establishing the cost justification defense at pp. 13-14 supra.

66 See note 35 supra. The encouragement of economic discrimination inherent in the Robinson-Patman Act is further highlighted by the denial of a cost justification defense where a violation of the brokerage provision, $\S 2(c)$, or the promotional arrangement provisions, $\$ \$ 2(\mathrm{~d})$ and $2(\mathrm{e})$, is charged. See, respectively, FTC v. Henry Broch \& Co., 363 U.S. 166, 176 (1960); FTC v. Simplicity Pattern Co., 360 U.S. 55, 70-71 (1959).

67 ICC v. Delaware L. \& W. R.R., 220 U.S. 235, 241 (1911); Providence Coal Co., 1 I.C.C. 107 (1887).

68 Thurber v. N.Y.C. \& H. R.R. Co., 3 I.C.C. 473 (1890); see Container Serv., 178 I.C.C. $377,434-35$ (1931).

69 But see occasional early cases such as Barrow v. Yazoo \& M.V. R.R., 10 I.C.C. 338 
from the development of a separate freight forwarder industry dedicated specifically to performing the service of consolidating LCL shipments into carload lots that the differential in rates exceeds the difference in costs.70 Thus, the ICC's general prohibitory policy tends to promote economic discrimination, while through the major exception to that policy-the carload-LCL differential-the ICC permits differentials which, by exceeding costs, also constitute economic discrimination.

The development of large-scale intermode competition, particularly from barges which are capable of carrying many times more freight than a rail car, led the ICC, beginning in 1939, to permit railroads to quote multiple carload rates in certain limited situations. ${ }^{71}$ Except for certain very recent cases, which are discussed below, the ICC has uniformly required that the reduced rates be granted only where the larger quantity was carried in a single shipment. Such multiple car rates may be instituted, according to the ICC's formulation of the rule, only where proved "to be compensatory, reasonably related to the single-car rates, and necessary to meet the competition of large-volume carriers."72 The substantive standard for a "compensatory" rate and the standards of proof required of the rail carrier proposing the multiple car rate, are matters which the ICC has not clarified with any high degree of precision, although in general terms a multiple car rate is "compensatory" where it covers "out-of-pocket" costs as defined by the ICC. ${ }^{73}$ The

(1904); Harvard Co. v. Pennsylvania Co., 4 I.C.C. 212 (1890). The breadth of the differential is, of course, subject to indirect regulation under the requirement that individual rates be "just and reasonable." See text accompanying notes $40-41$ supra.

70 See ICC v. Delaware, L. \& W. R.R., 220 U.S. 235, $243-45$ (1911); ScrwarTZ, FrEE ENTERPRISE AND ECONOMIC ORGANIZATION 521 (2d ed. 1959). The existence of "all freight" and "all commodity" rates, developed to meet truck competition, but used extensively by freight forwarders, may have something to do with the success of the freight forwarder industry. See National Resources Planning Board, Transportation and National Policy 105 (1942).

71 Asphalt to Iowa, Mich., Minn. \& Wis., 316 I.C.C. 117 (1962); Grain from Kansas City, Omaha \& Related Origins to Lawrenceburg, Ind., 315 I.C.C. 83 (1961); Pig Iron from Neville Island, Pa. to Louisville, Ky., 313 I.C.C. 771 (1961); Rock Salt from N.Y. to Del., Md., N.J., N.Y., \& Pa., 313 I.C.C. 197 (1961); Coal from Ill., Ind. \& Ky. to Ill. \& Ind., 308 I.C.C. 673 (1959); John Schutt, Jr., Inc. v. Pennsylvania R.R., 308 I.C.C. 217 (1959); Paper from St. Francisville, La. to Chicago, Ill., 306 I.C.C. 703 (1959); Eastern Coal to Chicago, Ill., 306 I.C.C. 195 (1959); Illinois Intrastate Coal Rates to East St. Louis, Ill., 304 I.C.C. 769 (1958); Ex-River Coal, Mount Vernon, 296 I.C.C. 489 (1955); Limestone from Prairie du Rocher, Ill. to Baton Rouge, 276 I.C.C. 381 (1949); Molasses from New Orleans to Peoria \& Pekin, 235 I.C.C. 485 (1939).

72 Asphalt to Iowa, Mich., Minn. \& Wis., 316 I.C.C. 117, 125 (1962). See also Pig Iron from Neville Island, Pa. to Louisville, Ky., 313 I.C.C. 771, 777 (1961); Rock Salt from N.Y. to Del., Md., N.J. \& Pa., 313 I.C.C. 197, 203 (1961).

73 See the conflicting opinions of Commission members on this issue in Limestone, Prairie du Rocher, Ill., to Baton Rouge, La., 313 I.C.C. 71 (1960). On ICC cost-finding 
"reasonably related" standard is even more indefinite. In some cases the ICG seems to have in mind a cost oriented interpretation which would require a showing that the savings in cost from multiple car shipments approximate the difference between the volume and carload rates, ${ }^{74}$ while in other cases it appears to consider that the test is whether the volume rate is so much lower than the carload rate that carload shippers suffer competitive injury. ${ }^{75}$ Where the only traffic of the commodity in question over the route in question will be that carried under the multiple car rate, the "reasonably related" standard appears to be ignored. ${ }^{76}$ The meeting competition requirement for a volume rate is the criterion most carefully adhered to and the ICC often undertakes a careful study not only of the rates of the competing carrier but also, at least where the competing carrier has not yet participated in the traffic under consideration, of the competing carrier's ability to carry the traffic profitably at that bid. ${ }^{77}$

In several relatively recent cases the ICC has permitted a volume rate not limited to a single shipment. No rule has yet been clearly articulated concerning the circumstances under which such multi-shipment rates will be approved. In Coal from Ky., Va., \& W. Va. to Virginia, ${ }^{78}$ the Commission permitted a volume rail rate for coal conditioned on the shipment of at least $1,500,000$ tons to a single consignee during a twelve month period. Here, unlike the multiple car, single shipment cases, the competition did not come from a mode of transportation under the jurisdic-

techniques, see icG, Explanation of Rail Cost Finding, Procedures and Principles Recating to THE USE OF Costs (1954); Meyer, ThE ECONOMICs of Competition IN THE Transportation Industries $274-347$ (1960). See also ICC v. New York, N.H. \& H. R.R., 195 F. Supp. $635,647-49$ (D. Conn. 1961), vacated and remanded, 372 U.S. 744 (1963).

74 See Paper from St. Francisville, La. to Chicago, Ill., 306 I.C.C. 703, 710 (1959); Eastern Coal to Chicago, Ill., 306 I.C.C. 195, 199 (1959); Molasses from New Orleans, La., to Peoria \& Pekin, IIl., 235 I.C.C. 485, 502 (1939).

75 See Coal from Ill., Ind. \& Ky. to IIl. \& Ind., 308 I.G.C. 673, 678 (1959), where the ICC, although conceding that "there is here no indication of a substantial difference in the cost of transportation under the proposed multiple-car rates and under the single-car rates," nonetheless found that the reduced volume rate was "properly related" to the carload rate. The Commission argued that the sole shipper of single carloads would not be injured.

76 See Grain from Kansas City, Omaha \& Related Origins to Lawrenceburg, Ind., 315 I.C.C. 83 (1961); Limestone, Prairie du Rocher, Ill., to Baton Rouge, La., 313 I.C.C. $71(1960)$.

i7 See Limestone, Prairie du Rocher, Ill., to Baton Rouge, La., 313 I.C.C. 71 (1960). But see Rock Salt from N.Y. to Del., Md., N.J., N.Y. \& Pa., 313 I.C.C. 197 (1961), where the competition came from ocean carriers outside the jurisdiction of the ICC. The comparison of rail costs with barge costs gives rise to important problems concerning relative costs in intermode competition which are beyond the scope of this paper. See notes $42-43$ supra.

78308 I.C.C. 99 (1959). 
tion of the ICC. The carrier established that unless the consignee in question, an electric utility, was granted the reduced volume rate, the latter would rely on coal from land which it currently had under option in the origin area and would substitute transmission line transportation of electricity for rail transportation of coal. Multiple car, single shipment volume rates were found inadequate to meet the competitive threat.79 The Commission noted that neither the shipper nor the consignee would be imposed upon by the volume rate.

Quantity rates based on yearly receipts by a consignee were also approved by the ICC in Coal to New York Harbor Area. ${ }^{80}$ At stake was the shipment of coal to electric utilities in the Middle Atlantic seaboard area and the principal competition was presented by residual oil which came from foreign countries by unregulated ocean carriers. The ICC emphasized that the proposed rates were compensatory and that the utilities did not compete with any other coal receivers in the destination areas so that no injury to competition would occur in the consignee's market. The decisive factor, according to the ICC, was that regulated railroads were in immediate danger of losing a substantial amount of coal traffic to unregulated ocean carriers of residual oil. Thus, the shipments to electric utilities, which alone purchased enough coal to qualify for the volume rates, were lawful. ${ }^{81}$

This exception to the general rule against multi-shipment volume rates which is thus being carved out on a case-by-case basis by the ICC will not necessarily serve to reduce economic discrimination. Cost savings through high volume are more likely to arise from larger quantities per shipment than from additional shipments per time period. For example, it is likely to cost the railroad less to carry fifty-two carloads of a commodity in a single train than to carry one carload of that commodity per train once each week for fifty-two weeks. Thus, it would probably be more consistent with a policy of discouraging economic discrimination to permit single shipment volume discounts than to permit volume discounts based on total shipments over a given time period. ${ }^{82}$ But whether the differential in question arises from a single

79 It should be noted that since the utility was the only purchaser of coal at the point of destination, the case was not truly one of personal discrimination (that is, between shipments of like commodities between common terminals over a single line), although the rates had initially been suspended on a $\$ 2$ theory.

80311 I.C.C. 355 (1960). The quantity rate was available on all coal in excess of $3,000,000$ tons to any one consignee, provided such consignee received not less than $5,500,000$ tons during the designated fiscal year. $I d$. at 360 .

81 The quantity rate was nominally available for all coal shipments to the area but only electric utilities consumed sufficient coal to be eligible. Id. at 356 .

82 The FTC has recognized this cost phenomenon in the sale of goods sector 
shipment or a multiple shipment volume rate, it is clear that the requirement that the competition came from a nonregulated rather than a regulated source has very little to do with the elimination of economic discrimination.

A variation on the volume rate practice is the contract rate in which a shipper receives a special rate in return for an agreement to ship a designated portion of his total shipments over a given period with the carrier granting the special low rate. ${ }^{83}$ The ICC, in recently disapproving several proposed contract rates, has relied upon the "destructive competitive practice" language of the National Transportation Policy without going so far as to consider the discrimination provisions of sections 2 and $3 . .^{84}$ The ICC has, however, announced that contract rates are "unlawful per se."

While a contract rate need not favor large over small shippers, all shippers being eligible for the discount if willing to commit themselves to ship the designated percentage within the designated time period, such

of the economy by refusing to find cost justified quantity discounts based on yearly volume of purchases. See note 61 supra.

83 In the unregulated sector such exclusive arrangements would give rise to antitrust problems under Section 3 of the Clayton Act and Section 1 of the Sherman Act, as well as Robinson-Patman Act questions. See New York Cent. R.R. v. United States, 194 F. Supp. 947, 951 (S.D.N.Y. 1961).

84 In Contract Rates on Rugs \& Carpeting from Amsterdam, N.Y. to Chicago, 313 I.C.C. 247 , aff'd sub nom. New York Cent. R.R. v. United States, 194 F. Supp. 947 (S.D.N.Y. 1961), aff'd per curiam, 368 U.S. 349 (1962), the ICC held unlawful as a "destructive competitive practice" a proposed reduced rate for rugs conditioned on the shipper's agreement to move eighty per cent of its annual volume of the traffic in question over the carrier's line.

85 Guaranteed Rates, Sault Ste. Marie, Ontario to Chicago, 315 I.C.C. 311, 323 (1961). While the ICC in holding unlawful the contract rates in Contract Rates on Rugs and Carpeting, note 84 supra, emphasized that competition of competing railroads and motor carriers would be affected, a more difficult case was presented in the Sault Ste. Marie case for there it did not appear-at least in the view of the dissenting Commissioners - that any competing carriers, regulated or unregulated, were prepared to offer competition to the railroads proposing the contract rates with respect to the shipments of pipe and tubing in question. Nevertheless, the Commission held that adoption of the contract rates would have a destructive affect on the competition of regulated water carriers. It is not clear whether the Commission was referring to immediate competition of water carriers over the route in question, or only to the potential competition of such water carriers or to the competition of water carriers generally if such contract rates should be applied to other commodities over this and other routes. Whatever the exact nature of the competition from regulated carriers the Commission had in mind in its murky opinion, it was this competition that the Commission felt distinguished the multi-shipment volume rates held lawful in Coal from Ky., Va. \& W. Va. to Virginia, and Coal to New York Harbor Area, where there was no competition from regulated carriers. Thus, although the Commission explicitly stated that contract rates are "unlawful per se," there is no definitive holding concerning the validity of contract rates where engendered by competition from unregulated carriers. 
rates may nevertheless lead to economic discrimination if the discount is substantial. A railroad undoubtedly may be able to reduce certain costs if it is able, through advance contracts, to estimate with increased precision future shipments, but it is doubtful that a contract rate system would give rise to sufficient cost savings to justify substantial contract rate discounts. The ICC's refusal to approve contract rates thus probably tends to discourage economic discrimination, even though the ICC has not analyzed the contract rate problem as one of economic discrimination. But since the question whether a contract rate involves economic discrimination presupposes a factual inquiry in which the differential between the contract rate and the regular rate is compared with the corresponding differential in costs, the ICC's "per se" prohibition is an uncommonly blunt weapon against economic discrimination.

\section{State Utilities Legislation}

Quantity discounts are a nearly universal phenomenon in the pricing of energy by electric utilities. The most common form of quantity discount is the block schedule ${ }^{86}$ under which total quantities purchased are divided into a series of blocks with the per-unit rate applicable to total quantity purchased decreasing as one moves from the lower quantity to the higher quantity blocks. ${ }^{87}$

Public utility commissions not only permit block schedules but actively encourage this form of differential pricing, at least so long as the lowest rate exceeds the incremental costs to the utility of providing the additional service. Such quantity discounts are thought desirable because they expand consumption of electricity by encouraging each consumer of electric service to increase purchases. ${ }^{88}$ Commissions do not

86 See Barnes, The Economics of Public Uthlity Regulation 338-39 (1942); Caywood, Electric Utility Rate Economics 43-47 (1956); Troxel, Economics of Public UTILITIES 600-02 (1955).

87 A variation of the block schedule is the step rate schedule. In each type of schedule, quantities consumed are classified into two or more blocks as zero to ten kilowatt hours (kwh), ten to fifty kwh, etc. The difference is that in the block schedule, a different per-unit rate is applied to purchases within each block whereas in the step rate schedule the block into which total consumption for the period falls determines the per-unit rate for all units consumed. The step rate schedule has the disadvantage that as one moves from one block to the next, a small increase in consumption may result in a substantial decrease in the total charge. A curve describing total cost as a function of consumption would show a series of "kinks" or "sawtooths." For this reason, electric utilities have tended to abandon step rate schedules in favor of block schedules. See CAYwood, op. cit. supra note 86, at 47-48; BARNEs, op. cit. supra note 86 , at $336-38$.

88 See, e.g., $R e$ Rates and Rate Structures, 1931C P.U.R. 337-55 (N.Y. Pub. Serv. Comm'n 1931); cf. Bilton Machine Tool Co. v. United Illuminating Co., 110 Conn. 417, 148 Atl. 337 (1930). 
seem to be troubled by the possibility of economic discrimination inherent in such discounts. 89

While all block schedules probably involve a good deal of economic discrimination, it should be noted that certain per-unit costs do differ with the quantity purchased. In analyzing utility costs, it is traditional to differentiate among three kinds: output, customer and capacity costs. $^{.0}$ Output costs are the costs of producing the energy itself, given the requisite plant and equipment; such costs tend to vary almost directly with the quantity provided to a customer. ${ }^{91}$. Customer costs involve those costs which do not vary substantially with the quantity purchased by a given customer but which nonetheless vary with the number of customers. Included are such items as periodic billing costs and the cost of installing the equipment necessary to provide service to the customer's establishment. ${ }^{92}$ Block schedules may reflect to a limited degree the higher perunit costs of serving low quantity customers rather than high quantity customers which may be attributed to the existence of such customer costs. But block schedules are very imprecise techniques for allocating customer costs among units of energy.

The third type of cost-capacity costs-varies with the number of customers and among customers but does not necessarily vary with the quantity purchased. ${ }^{93}$ Because a utility is required to provide service upon demand to all customers, it must have available at all times the plant capacity necessary to provide that service. Thus, a customer who consumes all purchased energy during one hour in the day which coincides with the peak load for the system as a whole will cause the utility to incur many times the capacity costs as will a customer who consumes the same total quantity at a constant rate throughout the day. Since capacity costs thus bear no necessary relationship to quantity purchased, block schedules fail entirely to reflect these differential costs. In an attempt to allocate such costs, many utilities have adopted, particularly

89 See $R e$ Edison Electric Illuminating Co., 1928D P.U.R. 859, 861-62 (Mass. Dep't Pub. Util. 1928). In considering block schedules, it should be borne in mind that electric utilities and, to a lesser extent, gas utilities also classify consumers by the use to which they put the product. Normal classifications include residential, commercial, industrial, etc. and within each such classification a separate block schedule will be constructed. Indeed, some commissions require classification if block schedules are used so that residential consumers have an opportunity to buy additional units of lower price blocks in the same manner as industrial consumers. See Public Util. Comm'n v. Oquossoc Light \& Power Co., 11 P.U.R. (n.s.) 25, 36-37 (Maine Pub. Util. Comm'n 1935).

90 See discussion of output, customer and demand cost in BARNEs, op. cit. supra note 86 , at $325-31$ (1942).

$91 \mathrm{Id}$. at 331.

92 Ibid.

93 Id. at 325-26. 
for industrial customers, two-part rates; one part contains a block schedule for energy consumed and the other part involves a special charge for units of capacity required to stand ready to serve the customer in question.94 While two-part rates may tend to reduce economic discrimination, its success in doing so depends upon the accuracy with which the capacity charge portion of the schedule reflects the incidence of capacity costs.

Other devices which produce differential per-unit net charges with varying quantities of service include minimum charges, ${ }^{95}$ which in effect require the customer to purchase a minimum quantity during each billing period, and lump sum service charges, ${ }^{96}$ which are added to each bill whatever the quantity purchased.

While service charges and, to a lesser extent, minimum charges are more convenient and less discriminatory methods for allocating customer costs they have been less frequently approved by state commissions than have block schedules. ${ }^{97}$ The difference in treatment may probably be attributed to the consumer resentment aroused by such charges which seem, to the popular mind at least, to require the consumer to pay something for nothing. ${ }^{88}$

\section{Crassification of Customers and Uses}

The second issue to be treated in comparative fashion under the three statutory schemes is the extent to which a seller is permitted to group his customers into classes, charging different classes different rates.

04 See BARNes, op. cit. supra note 86, at 339-43; TroxeL, op. cit. supra note 86, at 604-06; Davidson, Price Discrimination in Selling Gas and Electricity in 72 STUdies IN Historical and Political Science 83-92 (1954).

95 See BARNes, op. cit. supra note 86, at 345; Troxel, op. cit. supra note 86, at 607 .

96 See $R e$ City of Oconto Falls, 14 P.U.R. (n.s.) 237, 240-41 (Wis. Pub. Serv. Comm'n 1936); BARNEs, op. cit. supra note 86, at 357; TROXEL, op. cit. supra note 86, at 606-08.

97 See $R e$ Wisconsin Gas \& Elec. Co., 9 P.U.R. (n.s.) 517, 520-21 (Wis. Pub. Serv. Comm'n 1935); $R e$ Wisconsin Michigan Power Co., 4 P.U.R. (n.s.) 276, 279-80 (Wis. Pub. Serv. Comm'n 1934).

88 As the New York Public Service Commission explains, the "important fact" is that "regardless of facts and figures, the consumer is apt to consider the service charge ... as a charge for which the company renders no service or such small amount as to be negligible. . . . In other words, the fundamental objection to the service charge is not so much economic or accounting as it is psychological. Yet the effect upon the consumer is most important and cannot be ignored in any determination." Re Rates \&: Rate Structures of Corporations, 1931C P.U.R. 337, 347 (N.Y. Pub. Serv. Comm'n 1931) (emphasis in opinion). This type of xeasoning is carried even further by some commissions by requiring minimum charges in preference to service charges. See ibid; Re Public Serv. Co. 37 P.U.R.3d 485 (Ind. Pub. Serv. Comm'n 1961). A number of utility commissions have prohibited per-room rates for residential consumers particularly since large appliances have replaced lighting as the principle use for residential energy. See, e.g., $R e$ Wisconsin Michigan Power Co., 4 P.U.R. (n.s.) 276, 279 (Wis. Pub. Serv. Comm'n 1934); Re Detroit Edison Co., 16 P.U.R. (n.s.) 9, 38-39 (Mich. Pub. Util. Comm'n 1936). 


\section{A. Robinson-Patman Act}

In analyzing the Robinson-Patman cases governing classification of customers, it is important to distinguish between customers who purchase for resale and those who purchase for consumption, and in the latter case to distinguish between customers who are ultimate consumers and customers who merely use the purchased goods in the production of other goods. ${ }^{99}$ These distinctions arise because the degree of injury to competition required to establish a violation of the Robinson-Patman Act is much greater in the case of primary-line competition than in the case of secondary-line competition. Secondary-line injury is most apt to occur where the purchaser is a reseller because, under the Supreme Court's interpretation of the act in Morton Salt, a substantial difference in prices charged resellers will necessarily cause injury to the nonfavored reseller. ${ }^{100}$ Where, however, the seller's goods are used in the production of other goods, the price paid by the customer will normally constitute a much smaller percentage of his per-unit costs. Thus, the impact of the discrimination will be more problematical and indirect than in the resale case, and presumably Morton Salt does not require a finding of competitive injury merely from a showing of a substantial price differential. ${ }^{101}$ In some situations, even a rank discrimination against a manufacturer-customer cannot be shown to have affected the business of the nonfavored purchaser. Finally, where the purchasers are ultimate consumers there will be no competitive injury whatever within the meaning of the Robinson-Patman Act. ${ }^{102}$

Thus, so long as competition is not injured at the primary line, a seller may lawfully differentiate in price between (1) manufacturers and resellers, ${ }^{103}$ (2) manufacturers or resellers, on the one hand, and ultimate consumers on the other, ${ }^{104}$ (3) resellers on different levels of

99 Classification of customers is, of course, permitted even if there is an injury to competition provided the differential in prices is cost justified. But the standards for allocating costs by class are high, particularly where the individual classes encompass different types of purchasers. See United States v. Borden Co., 370 U.S. 460 (1962); Champion Spark PIug Co., 50 F.T.C. 30, $42-43$ (1953).

100 See discussion of Morton Salt in text accompanying notes 23-25, 58-60 supra. See also Moog Indus., Inc. v. FTC, 238 F.2d 43, 49 (8th Cir. 1956), aff'd, 355 U.S. 411 (1958).

101 See Minneapolis-Honeywell Regulator Co. v. FTC, 191 F.2d 786 (7th Cir. 1951), cert. dismissed, 344 U.S. 206 (1952).

102 Since ultimate consumers do not compete in sale either of the products in question or of products made therefrom, there is no competition at the ultimate consumer level to be injured. Cf. Yale and Towne Mfg. Co., 52 F.T.C. 1580 (1956).

103 See Champion Spark Plug Co., 50 F.T.C. 30, 36-37 (1953).

104 Informal opinions of the FTC, Biverage Syrup, 81 Cong. Rec. 2339 (app. 1937); Chicago Sugar Co. v. American Sugar Ref. 176 F.2d 1 (7th Cir. 1949); Sano Petroleum 
the distribution chain, such as wholesalers and retailers, at least so long as the differential favors distributor levels nearer the seller, ${ }^{105}$ (4) manufacturers not in competition with each other, ${ }^{106}$ (5) manufacturers in competition with each other, so long as the seller's product does not constitute the major element of cost for the manufacturers, ${ }^{107}$ and (6) ultimate consumers, however similarly situated.108 One may conclude the seller has very broad powers to classify customers, so long as he does not make classifications among resellers. In the last two situations, it will be noted, the Robinson-Patman Act permits differentials between customers who, under any standard, must be said to be similarly situated. Whatever may be said for the desirability of the foregoing distinctions, they have nothing to do with economic discrimination. Quite to the contrary, allowing differential prices to customers in noncompeting lines of business permits the seller to vary prices according to the differing elasticities of demand of the various classes of customers. In the act's own rather perverse manner, it is only where the customers' elasticities of demand are likely to be similar, as where they are both resellers on the same level of the distribution chain, that the act provides strict prohibitions against differentials based on classification.

Still another form of classification of customers may be legitimated by the principle that a non-cost justified price differential is unlawful under the act only where the goods sold to favored and nonfavored purchasers are of "like grade and quality." While granting that some such test is necessary to determine whether one or more products are involved, no clear guidelines have been consistently applied. The cases may be read to say that the act treats as of "like grade and quantity" substantially

Corp. v. American Oil Co., 187 F. Supp. 345 (E.D.N.Y. 1960); Secatore's Inc. v. Esso Standard Oil Co., 171 F. Supp. 665 (D. Mass. 1959).

105 The lower price given to the reseller nearer to the seller on the distribution chain is called a functional discount. The lawfulness of such functional discounts is well established, but an important limitation is that the level of resale, rather than the level of initial sale, is decisive in determining the reseller's level on the distribution chain. See Mueller Co., No. 7514, FTC, Jan. 11, 1962; General Foods Corp., 52 F.T.C. 798, 824 (1956). It may be, however, that a reseller further from the seller may not be given a discount, for in that case the nearer reseller would be injured. Thus, a lower price to a retailer than to a wholesaler might injure competition. Compare Krug v. Int'l Tel. \& Tel. Corp., 142 F. Supp. 230 (D.N.J. 1956) with Sano Petroleum Corp. v. American Oil Co. 187 F. Supp. 345 (E.D.N.Y. 1960). See also FTG v. Morton Salt Co., 334 U.S. 37, 55 (1948).

106 Cf. Yale and Towne Mfg. Co., 52 F.T.C. 1580 (1956). This principle would also seem to follow a fortiori from the fifth principle in the text.

107 See note 102 supra.

108 Cf. Corn Products Ref. Co. v. FTC, 324 U.S. 726, 739, 742 (1945); MinneapolisHoneywell Regulator Co. v. FTC, 191 F.2d 786 (7th Cir. 1951), cert. dismissed, 344 U.S. 206 (1952); see Edwards, The Price Discrimination LAW 234 (1959). 
identical goods sold under different brands and labels ${ }^{109}$ and goods which are physically highly similar where sold under identical brands and labels, ${ }^{110}$ but treats as not being of "like grade and quality" goods with quite distinct physical characteristics when not sold under identical brands and labels. ${ }^{111}$

\section{B. Interstate Commerce Act}

The Interstate Commerce Act purports to prohibit absolutely classification of customers. Thus, a carrier may not charge two shippers different prices for hauling a given commodity between two given points, and this absolute prohibition applies whether or not the shippers are in competition. ${ }^{112}$ Such a differential in price is considered to constitute personal discrimination and thus must pass muster under the strict prohibitions of section 2.113

The foregoing general principle is somewhat misleading, however, because a carrier which chooses to discriminate between customers may usually, by one means or another, accomplish that objective lawfully. For example, where shippers are engaged in shipping either from or to different points, a rate differential becomes a geographical differential to be tested under the more liberal proscriptions of section 3. Moreover, where shippers do not compete the carrier may be successful in justifying a differential on the theory that the commodities carried are not alike and thus the service sold to the shipper is different.114 The

'109 American Can Co. v. Bruce's Juices, 187 F.2d 919, modified, 190 F.2d 73 (5th Cir. 1951); Borden Co., No. 7129, FTC, November 28, 1962; Fruitvale Canning Co., 52 F.T.C. 1504, 1506 (1956); Page Dairy Co., 50 F.T.C. 395 (1953); United States Rubber Co., 46 F.T.C. 998, 1006-09 (1950); United States Rubber Co., 26 F.T.C. 303 (1938); In re Golf Balls Mfr. Ass'n, 26 F.T.C. 824 (1938).

110 Cf. Atlanta Trading Corp. v. FTG, 258 F.2d 365 (2d Cir. 1958); General Foods Corp., 52 F.T.C. 798 (1956).

111 For cases indicating that where different brands or labels are not used, physical differences must be substantial to avoid a finding of like grade and quality, see Moog Indus., Inc. v. FTC, 238 F.2d 43, 49-50 (8th Cir. 1956); American Can Co. v. Bruce's Juices, 187 F.2d 919, modified, 190 F.2d 73 (5th Cir. 1951).

112 A leading case is ICC v. Baltimore \& O. R.R., 225 U.S. 326 (1912), where the Supreme Court rejected the argument that a railroad might justify charging more for the shipment, between the same points of origin and distance, of fuel coal than commercial coal, even though the two kinds of coal did not compete, the fuel coal being used by railroads and the commercial coal being used by other types of consumers.

113 A price differential between shippers with respect to the same product or commodity between the same points also may be illegal under the looser prohibitions of $\S 3$ but the crucial test arises under the stricter provisions of $\S 2$. Section 3 becomes crucial only where different points of destination or origin are involved, or because different commodities are involved, $\$ 2$ is inapplicable.

114 The term "commodity" is used throughout this paper in a general sense to refer to all forms of freight, including industrial products. Where the term is used 
geographic differential will be separately discussed in a succeeding section of this paper, but the different service justification bears investigation at this point.

Railroads have traditionally charged sharply different pound-mile rates for different commodities. In general, the higher the value of the commodity, the higher the rate, although special costs associated with particular commodities are also frequently reflected in the rates. The resulting rate structures have become quite complex. Within any given rate territory, rates are divided into class rates and commodity rates. The number of class rates under the Uniform Freight Classification, which is now applicable in most of the United States, totals fifteen with rates varying from fifty-five per cent to four hundred per cent of an arbitrarily selected "average" class rate. Every product subject to the class rate classification is assigned a particular class. Some eighty-five per cent of freight travels, however, under commodity rates which are in a sense exceptions to the class rates. Each of the hundreds of commodities subject to commodity rate, rather than class rate, treatment is assigned an individual rate. ${ }^{115}$

The wide differences between various class and commodity rates are not closely related to differences in cost, whether of incremental costs or of the fully distributed variety. ${ }^{118}$ Moreover, it is apparent that the ICC encourages departures from cost differences in determining class and commodity rates. Under official Commission doctrine, two principles of rate making flourish side by side - cost of service and value of serviceeither of which principles may from time to time be used to support given rate differentials. ${ }^{117}$ Value of service has many meanings. It is used, for example, to refer to the observable principle that high value commodities will normally support a higher freight rate than low value commodities. ${ }^{118}$ The term is also used to refer to the maximum rate at which traffic with respect to a given commodity will still move. In still another sense, it reflects an equitable notion held by carriers and

in a special sense, as in the sense of "commodity rates" in contradistinction to class rates, the context should make the special usage clear.

115 With respect to class and commodity rate classification, see LockLIN, Economics of Transportation, 156-182 (5th ed. 1960).

116 See, e.g., United States Sugar Corp. v. Atlantic Coast Line R.R., 277 I.C.C. 193, 202-03 (1950). See also Bureau of Transport Economics and Statistics, INTERstate CoMmerce Commission, Value of Service in Rate-Making 201-16 (1959).

117 Id. passim.

118 That the market price of a product may be a less than adequate measure of "value" of the service involved in carrying that product cannot, of course, be denied. See Bonbright, Principles of Public Utility Rates 378 n.18 (1961); Locklin, op. cit. supra note 115, at 156-72. See also, All Commodities from New England to Chicago \& St. Louis, 315 I.C.C. 419 (1961). 
regulators that the burden of providing a transportation system ought to be placed on those shippers most able to pay, whatever the costs of handling their shipments. Whatever meaning may be assigned, a "value of service" principle has traditionally been used by the ICC in approving the practice of railroads of varying freight rates to reflect differences in the elasticity of demand. Since the elasticity of demand tends to be greater for high than for low value commodities, "value of service" notions have been particularly useful to railroads in justifying pricing of the most classically discriminatory character. ${ }^{119}$

In the discussion of the definition of economic discrimination, ${ }^{120}$ we concluded that though a seller imposed a differential in prices unrelated to the corresponding differential in incremental costs, we should not say that the seller had engaged in price discrimination unless the same product was involved in each case. In determining whether the railroads' practice of classifying commodities should be considered economic discrimination, the question thus becomes whether the same product is involved where a carrier provides transportation services with respect to two different commodities. At least three general situations involving commodity classification can be postulated. First, the commodities may be sufficiently similar that the railroad is able to transport both commodities with the same basic equipment at substantially the same costs. Second, the railroad may be able to transport both commodities with the same basic equipment but the incremental cost of transport for one is greater than for the other because of, for example, special handling costs. Third, the commodities may require quite different equipment, such as refrigerator cars for the one commodity and flat cars for the other, and therefore presumably different costs.

In the first case postulated, it would be fatuous to argue that the service provided is different for the one commodity than for the other. ${ }^{121}$ In the second case, the better view would seem to be that the service provided is the same, that the additional incremental costs of carrying

119 The ICC has not only approved value of service rate-making by railroads but has actively encouraged it by, for example, holding that rates for high value commodities are subject to special restrictions against reductions not applicable to low value commodities. See, e.g., Alcoholic Liquors from N.H. \& N.Y. to Tex. \& La., 315 I.C.C. 124, 127 (1961); New York, N.H. \& H. R.R. v. ICC, 199 F. Supp. 635 (D. Conn. 1961), aff'd, 372 U.S. 744 (1962). But see All Commodities, New England to Chicago \& St. Louis, 315 I.G.C. 419,425 (1961), for a strong dissent revealing that not all members of the Commission support value-of-service ratemaking.

120 See text at pp. 4-6 supra.

121 The clearest example of differential prices for identical transportation service arises out of the growing practice of containerization. See statement of James E. Haydon in Legal Problems in Containerization and Transportation Coordination, 28 ICC PrAc. J. 185, 188 (1960). 
the one commodity should be reflected by a proportional difference in the freight rates, and that any rate differential which is proportionately greater or lesser than the cost differential would involve economic discrimination. The third case is arguable since in one sense different production bases - that is to say, different kinds of equipment-are required to carry the two commodities. On the other hand, by far the greatest portions of the capital involved, the right of way, locomotives, terminals, etc., will be the same for all commodities, and the special costs for certain commodities-such as special cars-can be viewed as merely a difference in incremental cost. Under this latter analysis, the differential in costs of the special equipment should be reflected proportionately, but no more than proportionately, in the rates for the two commodities.

The ICC has not attempted, with limited exceptions, to use the discrimination provisions of the act to discourage the economic discrimination inherent in value-of-service commodities classification. Quite the contrary, it is only where the commodities in question have been considered sufficiently competitive so that competitive injury could occur to disadvantaged shippers that the ICC has applied the relevant discrimination provisions of section 3.122 Moreover, section 3 is a basis for eliminating the differential only where the higher rate causes actual competitive injury to the high rate shipper. ${ }^{123}$ Yet even where the two commodities compete and the rate differential causes injury, the Commission has sometimes refused to order elimination of the differential where the commodities differed significantly in value. In those situations the Commission has explicitly relied on the principle that "value of service" considerations are to be weighed in determining whether the discrimination is "undue" under section 3.124

While it is clear that "value of service" ratemaking often leads to rate

122 See the discussion of the role of competition in determining whether higher valued commodities should bear a higher rate than lower valued commodities in Cream of Wheat Co. v. Atchison, T. \& S.F. Ry., 91 I.C.C. 45 (1924); cf. Institute of Scrap Iron \& Steel, Inc. v. Akron, C. \& Y. R.R., 316 I.C.C. 55, 66-67 (1962). Section 2 is not applicable since it applies only to differences in rates for the same commodity.

123 Thus, in Aluminum Co. of America v. Atchison, T. \& S.F. Ry., 146 I.C.G. 363, 372 (1928), where a rate differential between aluminum on the one hand and tin and copper on the other was in question, the Commission held: "We cannot conclude that [undue prejudice and preference] exists merely because the rates are different and there is some competition between the metals. There must be a further showing that the difference in rates operated in some way to complainant's disadvantage in marketing aluminum." See also Arnovia-Buckingham Slate Co. v. Aberdeen \& R. R.R., 174 I.C.C. 767 (1931); Staley Mfg. Co. v. Wabash Ry., 167 I.C.C. 12, 15 (1930).

$12 \pm$ See Wm. Wrigley Jr., Co. v. Aberdeen and R. R.R., 161 I.C.C. 4I, 44 (1930); Ogden Packing and Provision Co. v. Atchison, T. \& S.F. Ry., 101 I.C.C. 236, 252 (1925); Coke Producers Ass'n v. Baltimore \& O. R.R., 27 I.G.C. 125, 147 (1913). 
differentials exceeding differences in incremental costs, it is not unlikely that in some cases the differential in rates between certain commodities of roughly equal market value is substantially less than proportional to the difference in incremental costs and hence also an example of economic discrimination. To be sure, differences in "cost of service" are recognized as a defense to a section 3 charge. ${ }^{125}$ But the ICC does not appear to have challenged rates which are substantially identical for two commodities despite substantial differences in "cost of service."

In defense of the ICG it must be recognized that the discrimination provisions are not the only weapons it may use against discrimination. For example, it has the power under sections 1 and 15 to hold either the high or the low rate unreasonable and to prescribe new rates. ${ }^{126}$ But this power has been used to control inter-commodity differentials only within the broadest limits. As in cases decided under the discrimination provisions, "value of service" constitutes one of the principal considerations in determining the "reasonableness" of individual rates. ${ }^{127}$

In summary, while official ICC doctrine holds that classification of customers is illegal per se, that principle applies only to transportation of the same commodity between the same points of origin and destination. The fact of the matter is that the ICC encourages classification of customers through classification of commodities, thereby making it possible for railroads to engage in classical textbook discrimination by pricing in accordance with the elasticity of demand for transportation services of each class of shippers, the value of the commodities serving under "value of service" conceptions as a workable rule of thumb for determining elasticity. ${ }^{128}$ One recent empirical study suggests that the

125 See, e.g., Robertson Co. v. Alabama Great So. R.R., 167 I.C.C. 693 (1930).

126 See discussion at p. 16 supra.

127 See Bureau of Transport Economics and Statistics, Interstate Commerce Commission, Value of SeRvice in Rate-Making (1959).

128 The ICC has freely acknowledged that railroads classify commodities on other than a cost-of-service basis and has suggested that the greater attention paid to cost-ofservice considerations in recent years in justifying classification schemes lies not in a preference for cost-of-service over value-of-service ratemaking but rather in the competition of other modes of transportation which has tended to make high rates assigned in previous years too high to be competitive in the light of the new competition. Thus, in Class Rate Investigation, 1939, the Commission described railroad classification practices as follows: "Formerly, when the railroads had practically a monopoly of transportation, the principle given the greatest consideration was value of service, described as the ability to bear a particular rating with profit to the shipper or manufacturer and the railroads. Less weight was accorded the cost of service element. Development of competitive transportation agencies with flexible service, and a disregard of the element of value by the competitive agencies in the determination of their charges, have reacted upon the policies of the classification committees with the result that generally weight density is now the dominant consideration in determining classification ratings. This does not mean that value and 
degree of economic discrimination resulting from such value-of-service ratemaking is quite substantial. ${ }^{129}$

\section{State Utilities Legislation}

Electric utilities classify customers and uses in a number of different ways, principally by type of purchaser, by time of purchase and by type of power.

In the first type of classification, electric utilities have traditionally differentiated among the principal classes of power consumers, such as industrial, commercial and residential purchasers. ${ }^{130}$ Sometimes the classification is carried much further, as between types of industrial purchasers. ${ }^{131}$ Utility commissions have favored such differentials, usually without considering whether or not economic discrimination is involved.132 They have often approved special rates to new industrial consumers to induce establishment of plants in the community. It is only when the purchasers are so similarly situated that no rational basis for distinction appears, ${ }^{133}$ or where the rates to one class are not high

other principles of classification are completely eliminated from consideration; but it does mean that the value of an article does not control the rating to the extent it formerly did." 262 I.C.C. $447,481-82$ (1945). This analysis, far from demonstrating that cost-of-service has become the controlling principle, suggests that value-of-service remains the decisive principle because the railroads continue to attempt to maximize profit with respect to each kind of traffic without reference to the respective costs of carriage. The reduction of rates on certain classes of traffic in the face of competition is simply that reduction which is necessary to maximize profits in the light of the new competitive conditions.

129 "Value-of-service rate-making is a trade practice with an almost one-to-one correspondence with the economic model of the discriminating monopolist." MEYER, THE Economics of Competrion in the Transportation Industries 170 (1960). See $i d$. at 170-74, for an analysis of the ICC-approved rate level increases, tending to show that rates on high valued commodities are increased by a greater percentage than low valued commodities. See also Trone, EConomics of TrANSPORT 662.64 (1955).

130 Barnes, The Economics of Public Utictry Regulation 324, $334-35$ (1942); Gaywood, Electric Utultry RATe Economics 67-68 (1956).

131 "Special rates, even with only one customer being supplied thereunder, in themselves have not been considered discriminating nor unusual by the Commission in the past where the rates were designed to meet the peculiar demands of the customers' business, equipment, or conditions. . . . Our tariff files are full of special rates for one customer which this Commission seems to justify." Cavert Wire Co. v. Pennsylvania Power Co., 51 P.U.R. (n.s.) 248, 253 (Pa. Pub. Util. Comm'n 1943). (Emphasis in original.)

132 E.g., Smith v. Public Serv. Comm'n, 351 S.W.2d 768 (Mo. Sup. Ct. 1961); Re Wholesale Rates for Electric Power to Rural Cooperatives, 19 P.U.R. (n.s.) 22 (Ky. Pub. Serv. Comm'n 1937). Residential consumers are sometimes classified by the number of rooms or of electric outlets in their houses, although this kind of classification has become less frequent with the development of meters. See Caywood, op. cit. supra note 130 , at 44 . It is sometimes used, however, in determining the "demand" charge in two-part rates. See also BARNEs, op. cit. supra note 130, at 340-43.

133 One rather sophisticated commission has justified low rates for industrial 
enough to cover out-of-pocket costs and make a contribution to overhead, ${ }^{134}$ that utility commissions have found the differential rates to constitute discrimination under the applicable statutes. While it is occasionally argued that service to industrial purchasers is less costly than to residential purchasers, it is likely that the saving is only that which might more appropriately be recognized by a quantity discount or by a special off-peak discount where the industrial purchaser operates at off-peak hours.

The second category of classification-by time of purchase-can be traced to technological considerations. Because electricity cannot be stored and the demand, varying from moment to moment, reaches a "peak" once a day and because the electric company as a "public utility" has a duty to serve all members of the public, its plant must be large enough to serve that daily peak demand.135 Because considerable excess capacity is available most of the day many utilities have instituted, particularly with respect to industrial accounts, different rates for "peak" and "off-peak" consumption. ${ }^{136}$ Economists have engaged in a good deal of highly technical debate concerning whether, and under what circumstances, such differentials constitute economic discrimination. It seems

consumers on a "diversity factor" theory to the effect that peak-load capacity is required per unit actually consumed to service industrial consumers. See Wisconsin Pub. Serv. Corp., 7 P.U.R. (n.s.) I (1934).

134 Re Southern California Edison Co., 6 P.U.R. 3d 161, 206 (Cal. Pub. Util. Comm'n 1954); Consumers v. Edison Elec. Illuminating Co., 1926A P.U.R. 525 (Mass. Dep't Pub. Util. 1925).

135 While railroads also tend to have peak-load problems, though with a seasonal rather than a daily frequency (daily railroad peaks normally being limited to carriage of commuting passengers), the railroads have not, to any substantial extent, offered off-peak discount rates and therefore, the ICC's attitude toward such discounts has not been defined. See Neison, Ratrroad Transportation and Public Policy 363 (1959); Borts, Increasing Returns in the Railroad Industry, 42 J. PoL. Econ. 316, 327-33 (1954). In the unregulated sector, seasonal peaks are also common, but at least with respect to commodities (as opposed to services) to which the Robinson-Patman Act is applicable, it is possible to solve the seasonal problem to a certain extent through inventories. Though in one sense no discrimination exists with respect to off-season discounts since all purchasers during the off-season purchase at the same time, the Robinson-Patman Act permits discrimination between purchasers buying at different times only to the extent justified by the "changing conditions" proviso to \& 2(a) which specifies that "nothing herein contained shall prevent price changes from time to time wherein response to changing conditions affecting the market for or the marketability of the goods concerned, such as but not limited to actual or imminent deterioration of perishable goods, obsolescence of seasonal goods, distress sales under court process, or sales in good faith in discontinuance of business in the goods concerned." The scope of the "obsolescence of seasonal goods" clause remains to be defined. See generally, Rowe, Price Discrimination Under the Robinson-Patman Act 321-29 (1962).

136 GaYwood, op. cit. supra note 130 , at 68. 
generally agreed that because peak and off-peak power are joint products in the sense that the off-peak power is an inevitable by-product of producing power to meet peak demand, a lower price designed to clear the off-peak supply does not necessarily involve economic discrimination. One could either say that the products are different or that, since peak load power must be produced whether or not off-peak power is sold the bulk of costs should be allocated to peak load sales. ${ }^{137}$ Utility commissions have not been bothered with such troublesome theoretical questions, however, and have generally supported such pricing. ${ }^{138}$

Another consequence of the nonstorable quality of, and the fluctuating demand for, electric power is the utilities' practice of classification by types of power. In addition to sale of power at regular rates, electric utilities also frequently sell at sharply lower rates, particularly to industrial purchasers, interruptible power (interruptible under certain conditions), ${ }^{139}$ and, at still lower rates, dump power (interruptible without condition). Commissions apparently favor such differentiation of product.140 This form of classification is not essentially different from classification by time of purchase. Interruptible and dump power sales are merely different instances of off-peak sales. The peak, rather than occurring daily, occurs irregularly through the year. An important question of fact may often be involved, however, because if power is never in fact interrupted, the classification may be merely a technique for selling at different rates to purchasers with different elasticities of demand.

\section{Grographical Price Discrimination}

\section{A. Robinson-Patman Act}

Geographical pricing problems which have led to litigation under the Robinson-Patman Act arise from two principal facts of business life. The first is that incremental costs of sales to different purchasers tend to increase with the distance of the purchaser from the point of production because goods must be transported to purchasers. Thus, if prices do not reflect these incremental freight costs, economic discrimination is inevitable. Further, if the FTC should consider the mill net return as the

137 See Bonbright, op. cit. supra note 118, at 359-60; Hirshleifer, Peak Loads and Efficient Pricing, 72 J. OF EcoN. 451, 457-62 (1958).

138 But see Re Wisconsin Pub. Serv. Corp., 7 P.U.R. (n.s.) I (Wis. Pub. Serv. Comm'n 1934), for an exceptional commission attempt to analyze off-peak differential problems.

139 See BoNBrIGHT, op. cit. supra note 118, at 335; CAYwood, op. cit. supra note 130, at 70 .

140 Cf. Wolf v. United Gas Pub. Serv. Co., 77 S.W.2d 1091 (Tex. Ct. of Civ. App. 1935) (gas utility); Cock v. Marshall Gas Co., 226 S.W. 464 (Tex. Ct. of Civ. App. 1920) (gas utility). But cf. Re New York State Elec. \& Gas Corp., 6 P.U.R. (n.s.) 113 (N.Y. Dep't of Pub. Serv. 1934). 
"price" within the meaning of the "to discriminate in price" clause of section 2(a), the quoting of geographically uniform delivered prices would give rise to serious Robinson-Patman Act problems. The seller might avoid this problem by quoting prices F.O.B. plant but here he would run into the other horn of a legalistic dilemma. Prices which reflect differential freight costs result in differential price quotations and, if the actual price quotation is to be considered the "price" under section 2(a) and if injury to competition can be demonstrated, result in a prima facie case of price discrimination. The FTC, after a false start, ${ }^{141}$ came down on the side of the actual price quotation rather than the mill-net return as the relevant "price" for a prima facie case. ${ }^{142}$ At first blush, that conclusion would appear to promote uniform delivered prices and hence economic discrimination. ${ }^{143}$ The FTC's response has been that price differentials reflecting freight differentials may be justified by the seller under the cost justification provisions of the act.

The second fact of business life leading to geographical price discrimination questions under the Robinson-Patman Act is that not all sellers function in markets of similar geographic size. Thus, national sellers frequently compete with regional and local sellers with the result that any regional or local price reduction by national sellers may give rise to a charge of predatory discrimination. The popular image of predatory price-cutting is that a national seller, in competition in a local market with small local sellers, reduces prices to drive local sellers out of business. It is highly questionable whether such predatory price-cutting often occurs. A national seller, though possessing a larger treasury, can only afford to cut prices to drive local competitors out of business if his losses will not be greater than the gains he will be able to derive from increasing prices after competition is destroyed. Such predatory price-

141 See FTC and Supreme Court opinions in Cement Institute, 37 F.T.C. 87, 256-57 (1943), vacated, 157 F.2d 533 (7th Cir. 1946), reinstated, 333 U.S. 683, 722-25 (1948).

142 Chain Institute, Inc., 49 F.T.C. 1041, 1105 (1953); National Lead Co., 49 F.T.C. 791, 881-82 (1953), modified, 227 F.2d 825 (7th Cir. 1955), rev'd, 352 U.S. 419 (1957); Clay Prod. Ass'n, 47 F.T.C. 1256, 1273 (1951). The FTC's Advisory Committee on Cost Justification, reporting in 1956, expressed the rule as follows: "In all instances of 'geographic' or 'delivered' pricing the intent of the parties must be considered-what they mean the price to be. If the arrangement is for the buyer to transport the goods, or pay for the transport, the price obviously does not include freight charges (e.g., $\$ 1$ per dozen f.o.b. seller's factory, no freight allowed). On the other hand, if it is understood that the seller will transport the goods to the buyer or pay for the transport (e.g., \$1 per dozen f.o.b. buyer's plant, or \$l per dozen f.o.b. seller's plant, full carload freight allowed). In each case (whether transportation is prepaid or allowed) the price is $\$ 1$ per dozen, i.e., there is no price differential. In finding price it is reality that counts, not form; it is, for example, of no consequence that in one case the seller pays the freight and in another the buyer pays it and deducts the amount on payment of the invoice; either way freight is at seller's cost."

143 See Atr'y. Gen. Nat'z Comar. Antitrust Rep. 216-17 (1955). 
cutting can therefore be practiced only if competition can be driven out quickly so that losses will be minimized, ${ }^{144}$ and if entry by new competitors or reentry by the same competitors can be sufficiently delayed so that monopoly prices can be charged long enough to secure the projected profits. However infrequent such predatory price-cutting, the vital point is that it is this special form of price differential that the FTC has sought to prove in most geographic differential cases. ${ }^{145}$ The differential between the reduced price in the local market and the unreduced price elsewhere is relied on to establish the "discrimination." The crucial question thus becomes, assuming there is no possibility of establishing a cost justification or meeting competition defense, whether the requisite injury to competition can be established. Since the favored and disfavored purchasers are by hypothesis not in competition (for otherwise the predatory purpose could not be accomplished), the relevant test of competitive injury thus becomes the primary-line criterion which requires an injury to competition among sellers extending beyond mere diversion of business from competing sellers. ${ }^{148}$ Indeed, most of the cases dealing with primary-line injury have involved geographic differentials. ${ }^{147}$ In geographic discrimination cases, however, there is a tendency to permit proof of predatory intent as a substitute for proof of actual injury to competition at the primary level.148

14.4 See McGee, Predatory Price Cutting: The Standard Oil (N.J.) Case, 1 J. LAw \& EcoN. 137, 138-43 (1958).

145 The great Standard Oil case of 1911 is usually cited as an example of predatory price-cutting. A careful review of the record, however, has failed to reveal substantial evidentiary support for that conclusion. See id. at 168.

146 Maryland Baking Co. v. FTC, 243 F.2d 716 (4th Cir. 1957); E.B. Miller \& Co. v. FTC, 142 F.2d 511 (6th Cir. 1944); cf. Moore v. Mead's Fine Bread Co., 348 U.S. II5 (1954); Atlas Bldg. Prod. Co. v. Diamond Block \& Gravel Co., 269 F.2d 950 (10th Cir. 1959); See also Porto Rican American Tobacco Co. v. American Tobacco Co., 30 F.2d 234 (2d Cir. 1929), decided under the predecessor statute. As the Director of the FTC Bureau of Litigation has put the Commission's litigation policy: "The basic theory underlying the intent of Congress in declaring 'area' price discriminations to be violations of the law is generally that of preventing predatory use of market subsidization. In other words, the law hits at the practice of throttling local competition by lowering prices in one geographical area while maintaining higher prices in other areas. It seeks to prevent a large seller, with an interstate treasury, from subsidizing diminution or complete elimination of profits occasioned by discriminatory price cuttings in one and, by maintaining-or perhaps raising-its normal profitable pricing structure in other areas. . . Remarks of Joseph E. Sheehy, quoted in Edwards, The Price Discrimination LAw 452 (1959); see Anheuser Busch, Inc. v. FTC, 289 F.2d 835 (7th Cir. 1961), on remand from FTC v. Anheuser Busch, Inc., 363 U.S. 536 (1960); Balian Ice Cream Co. v. Arden Farms Co., 231 F.2d 356 (9th Cir. 1955); Purex Corp., Ltd., 51 F.T.C. 100 (1954); General Foods Corp., 50 F.T.C., 885 (1954); discussion at pp. 11-13 supra.

147 See Adelman, Geographical Price Differentials, 48 ILL. BAR Ass'N J. 514, 514-18, 519 (1960).

148 One important aspect of the law governing geographic differentials is that the 
Where predatory price-cutting in the strict sense does not exist and where the geographical price differential reflects only the difference in the degree of competition in two markets (as where the national seller faces more effective rivalry in one market than another), it is not clear that the differential prices should be considered to be economic discrimination. To resolve that question one must answer the definitional question, posed in an earlier section, whether differential pricing arising from differences in purchasers' tastes, should be considered to constitute economic discrimination. ${ }^{149}$

\section{B. Interstate Commerce Act}

Since geographical differentials involve different hauls and hence dissimilar "circumstances and conditions," they need not comply with the strict provisions of section 2. Rather, such differentials cases are tested under the more liberal undue preference and prejudice test of section 3, except in the limited situation where the two hauls occur over the same line in the same direction, the shorter being included within the longer, where section 4 establishes a special rule. Unfortunately, we have no authoritative statement of the elements of a section 3 offense where shipments are made over different routes. Certainly the statutory language requiring an "undue or unreasonable preference or advantage [or] prejudice or disadvantage" helps very little. It is sometimes said that a section 3 violation consists of rate relationships based on other than "transportation" considerations (unless justified by competition). ${ }^{\mathbf{1 5 0}}$ But neither the ICC nor the reviewing courts have fashioned the "transporta-

Robinson-Patman Act treats the multi-plant firm as a single entity even though the costs of the two or more production bases are sharply different. Thus, if an East Coast plant sells at a lower price than a West Coast plant of the same firm and thereby injures competition, the burden shifts to the defendant to establish that the differential is fully justified by differences in costs. The burden of cost justification tends to be difficult for defendants to meet under any circumstances (see discussion at pp. 13-14 supra) and will be particularly difficult to meet where separate plants, and perhaps even different accounting systems, are involved. Moreover, there is a substantial question whether differences in manufacturing costs between two plants constitute differences "resulting from the differing methods or quantities in which such commodities are to such purchasers sold or delivered," such differences alone being justifiable under the act.

149 See discussion at pp. 7-8 supra. The analogy to dumping is readily apparent. Does a monopolist whose home market is protected by tariff barriers engage in economic discrimination when he sells abroad in competition with local sellers at a competitive price which is lower than the monopoly price charged at home? See generally Viner, Dumping: A Problem in International Trade (1923).

150 See, e.g., Fargo Chamber of Commerce v. Akron, C. \& Y. R.R., 306 I.C.C. 407, 412 (1959); Bureau of Transport Economics and Statistics, Interstate Commerce Commission, Value of Service in Rate-Making 132, 151 (1959); Locklin, Economics of Transportation 497 (5th ed. 1960). 
tion" concept into a useful tool. ${ }^{151} \mathrm{Mr}$. Justice Brandeis was hardly helpful when he declared:

To bring a difference in rates within the prohibition of section 3 , it must be shown that the discrimination practiced is unjust when measured by the transportation standard. In other words, the difference in rates cannot be held illegal, unless it is shown that it is not justified by the cost of the respective services, by their values, or by other transportation conditions. ${ }^{152}$

By incorporating value of service notions Mr. Justice Brandeis was surely suggesting that the revenues to be obtained at various levels of potential rates was a factor to be considered, an approach which, as we have seen, tends to encourage economic discrimination. ${ }^{153}$

Despite such broad pronouncements, the ICC has tended to restrict itself to various rough measures of the comparative cost of the respective services in determining whether geographical rate relationships violate section 3. Sometimes cost studies of one form or another have been prepared. ${ }^{15 *}$ But since the costs of differing hauls are difficult to isolate, the ICC has often been forced to rely on respective distances as a rough measure of differential costs. ${ }^{155}$ In the process of comparing distances certain other factors such as topographical conditions ${ }^{156}$ and traffic

151 See, e.g., the confusing discussion of the cases in BUREAU OF Transport ECONOMICS AND STATISTICs, op. cit. supra note 150, at 132-53.

152 United States v. Mllinois Cent. R.R., 263 U.S. 515, 524 (1924). (Emphasis added.)

153 See statement of ICC policy toward value-of-service rate-making in regulation of inter-commodity differentials, pp. 33-34 supra.

154 Where the distances to the allegedly prejudiced point differ from the distance to the allegedly preferred point, the failure of costs to increase proportionately with distance adds a complicating dimension to the inquiry. Because of loading, unloading and similar costs which must be incurred for each haul but which do not vary with the length of the haul, the ICC has recognized a "tapering" principle under which, transportation conditions being otherwise similar for two hauls, the shorter haul should demand a rate which, on a per-mile basis, exceeds the rate on the longer haul. Cf. Mayo Shell Corp. v. Baltimore \& O. R.R., 297 I.C.C. 133 (1955). See also Troxel, Economics of Transport 671-72 (1955).

155 Fargo Chamber of Commerce v. Akron, C. \& Y. R.R., 306 I.C.C. 407 (1959); Buckeye Sugars v. Baltimore \& O. R.R., 302 I.C.C. 351 (1957); Mayo Shell Corp. v. Baltimore \& O. R.R., 297 I.C.C. 133 (1955); New Orleans Traffic \& Transp. Bureau v. Aberdeen \& R. R.R., 296 I.C.C. 59 (1955). See discussion of comparison of distances in State Corp. Comm'n v. United States, 128 F. Supp. 646 (D. Kan. 1954). See Sharfman, The Interstate Commerce Commission pt. III, vol. B, pp. 541-42, 567-69 (1936). But the ICC has held that the "mere showing that there are lower rates in effect to a more distant point does not in and of itself prove that the rate assailed was or is unreasonable or unduly prejudiced." Phillips Petroleum Co. v. Louisiana \& Ark. Ry., 270 I.C.C. 789, 790 (1948). See also Commodity Credit Corp. v. Texas \& Pac. Ry., 306 I.C.C. 525,533 (1959).

156 See, e.g., Cedar Hill Coal \& Coke Co. v. Colorado \& So. Ry., 16 I.C.C. 387, 391 (1909); cf. Railroad Comm'n v. Missouri \& N.A. R.R., 30 I.C.C. 488, 489 (1914). 
density ${ }^{157}$ have occasionally been taken into account in arriving at a judgment whether the differences in rates fail to reflect differences in the costs of service.

Aside from the cost-of-service standard, certain other elements of a section 3 violation are well established. Section 3 is not violated unless shippers in favored localities compete with shippers in disfavored localities ${ }^{158}$ and actual injury is sustained either in the form of injury to particular disfavored shippers ${ }^{159}$ or to the general economy of the disfavored locality. ${ }^{160}$

In its regulation of discrimination among localities, the ICC has in general pursued policies more consistent with elimination of economic discrimination than has the FTC. Thus, the ICC has recognized that identical rates may be discriminatory if costs differ and that a shipper charged a rate which is lower than that charged a second shipper may be discriminated against if costs are more than proportionately lower on the low rate haul.161

157 Traffic density, while doubtless having a direct impact on per-mile costs of transporting a given commodity is, nevertheless, a troublesome standard because greater density on the preferred haul may itself be the consequence of the rate preference. See Baltimore Chamber of Commerce v. Ann Arbor R.R., 159 I.C.C. 691, 705-06 (1929); cf. Indianapolis Chamber of Commerce v. Gleveland, C.C. \& St. L. Ry., 60 I.C.C. 67, 75 (1920). See also Sharfman, The Interstate Commerce Commission pt. III, vol. B, p. 570 (1933).

158 See Western Carolina Shippers' Ass'n v. Ashville So. Ry., 174 I.C.C. 353, 358 (1931); Kistler Leather Co. v. Pittsburg S. \& No. R.R., 169 I.C.C. 247, 252 (1930).

159 See City of Moorhead v. Great No. Ry., 172 I.C.C. 38, 43 (1931); Federated Metals Corp. v. Pennsylvania R.R., 16I I.C.C. 287 (1930); United States Phosphoric Prod. Corp. v. Butte, A. \& P. Ry., 153 I.C.C. 459,465 (1929). The extent of injury, it has recently been indicated, need be no more than a reduction in the disfavored shipper's profit margin. Mayo Shell Corp. v. Baltimore \& O. R.R., 297 I.C.C. 133, 135 (1955); Mayo Shell Corp. v. Akron, C. \& Y. R.R., 296 I.C.C. 507 (1955); cf. Anchor Coal Co. v. United States, 25 F.2d 462 (S.D.W. Va. 1928). Injuries to competing modes of carriage (primaryline injury in Robinson-Patman lexicon) are usually treated under the minimum rate power of $\S 15$ rather than under the discrimination provisions of $\S 3$. See discussion at notes $42-43$ supra.

160 See New York v. United States, 331 U.S. 284, 309, 310-32 (1947). "The great discrimination cases of the twentieth century have been really pitched battles between the Manufacturers' Associations or Chambers of Commerce of competing localities, sometimes widely separated geographically, but inextricably linked economically." Comment, 40 YALE L.J. 600, 602-03 (1931).

161 Rich Ladder \& Mfg. Co. v. Akron, C. \& Y. Ry., 241 I.C.C. 475, 482 (1940); Northern Potato Traffic Ass'n v. Atchison, T. \& S.F. Ry., 178 I.C.C. 237, $245-47$ (1931). See also Texas and Pac. Ry. v. United States, 289 U.S. 627, 655 (dissenting opinion by Mr. Justice Stone). But see Anchor Coal Co. v. United States, 25 F.2d 462, 471 (S.D.W. Va. 1928). The cases cited do not, however, prove that the ICC is fully cognizant of the nature of economic discrimination. In each case the lower gross rate, found to be a discrimination in favor of the shipper paying it, was really the lower rate on a per-mile basis. What one would want to find, to be certain that the ICC grasped the notion of economic discrimination, is a case in which a lower per-mile rate was found to be a discrimination 
In one very important class of cases, the group rate cases, the ICC has not only failed to construe section 3 in a manner designed to reduce economic discrimination, but has given it strong support. In general, railroad freight rates for any commodity tend, on a per-mile basis, to decrease as distance increases from any given point of origin or destination. However, in certain parts of the country with respect to certain commodities, railroads have adopted the practice of grouping points of destination so that the aggregate rate to the further point is the same as to the nearer point. Points of origin have also frequently been grouped in the same way. It cannot be gainsaid that some decrease in per-mile rates with increase in distance is consistent with nondiscriminatory prices because of the tendency, particularly in view of costs of loading and unloading which are common to any haul, of the incremental costs of hauls to decrease on a per-mile basis with increases in distance. ${ }^{162}$ No part of the difference in costs between the shorter and the longer hauls is reflected, however, in group rates, and therefore, where a single carrier serves two grouped points, economic discrimination is inevitable. Doubtless, a good deal of the economic discrimination resulting from group rates may be considered de minimis on the grounds that administrative convenience requires grouping of closely located points; certainly it would be a physically impossible task to quote rates from every point of origin to every point of destination in the country. To put the administrative convenience point somewhat differently, the costs of quoting different rates to every different point within small geographical areas would exceed the differentials in the aggregate of other costs of providing service to those points. Nevertheless, the points frequently grouped cover such an extensive geographic area that the grouping cannot possibly be justified on grounds of administrative convenience. For example, for shipments of certain commodities from points on the Pacific Coast, the entire area east of the Missouri River, and in some cases east of Denver, constitutes a single destination group. ${ }^{163}$

Grouping of rates has been defended by the railroads and viewed by

in favor of the shipper paying it. In the absence of such a case, it may well be that the ICC has shown no more sophistication than the FTC under the Robinson-Patman Act for the FTC also uses the per-unit price rather than the gross price in passing on charges of discrimination.

102 This principle has been recognized by the Commission from the beginning. See Williams Co. v. Vicksburg S. \& P. Ry., 16 I.C.C. 482, 487 (1909); New Orleans, Cotton Exch. v. Cincinnati, N.O. \& T.P. R.R., 2 I.C.C. 289, 293 (1888).

103 See Senate Committee on Interstate and Foreign Commerce, Merchant Marine Study and Investigation, S. REP. No. 2494, 81st Cong., 2nd Sess. (1950); LockLIN, Economics of Transportation 201 (4th ed. 1954). Oranges delivered to the New York market are subject to the same total transportation charge whether the point of origin is Florida or California. 
the ICG as a technique for promoting competition by permitting, for example, distant shippers to compete with shippers located nearer to buyers. ${ }^{164}$ Despite frequent protestations that a discrimination may not be justified on the grounds that it offsets the geographical advantages of more favorably situated points of origin or destination, ${ }^{165}$ the ICC has given little attention to the possibility that grouping, by depriving better located sellers of their economic advantage of proximity to buyers, may tend to encourage the expansion of resources committed to transport services, thereby causing misallocation of resources in the economy. Under the ICC's approach an origin group, for example, becomes too large only where the group is large relative to the length of the haul and the nearer shippers are seriously injured by competition from more distant shippers. ${ }^{166}$ This standard of injury required for a violation appears to be much higher than that applicable to rate relationships other than group rates. ${ }^{167}$

The ICC's favorable attitude toward grouping of rates reaches far beyond mere permissiveness. It is reluctant to disband established groups where the more distant enterprises have developed in reliance on group rates. ${ }^{168}$ And it has on occasion required the expansion of groups over carrier opposition. ${ }^{169}$

164 See A. C. Dutton Lumber Corp. v. New York, N.H. \& H. R.R., 151 I.C.C. 391, 412 (1929); cf. Galloway Coal Co. v. Alabama Great So. R.R., 40 I.C.C. 311,320 (1916). The creating-competition principle has also been applied by the Commission to justify destination groups. See Eastern Bituminous Coal Ass'n v. Baltimore \& O. R.R., 299 I.C.C. $691,715-16$ (1957). The ICC has argued that grouping of origin points is peculiarly appropriate for natural resource shipments. Chicago Gravel Co. v. Atchison, T. \& S.F. Ry., 118 I.C.C. 633, 645 (1926); Wisconsin \& Arkansas Lumber Co. v. St. Louis, I.M. \& S. Ry., 33 I.C.C. 33, 36-38 (1915). On the ICC's attitude toward group rates, see generally Sharfman, The Interstate Commerce Commission pt. III, vol. B, pp. 670-91 (1936); Comment, 98 U. PA. L. REv. 204 (1949). It must be recognized that the regulatory system itself sometimes leads to grouping of rates. Where a carrier faces competition on a long haul but not at intermediate points, $\S 4$, by prohibiting charging more for the short than the long haul, tends to require the carrier to place both the intermediate and the distant points in a single destination group. The carrier may, of course, assert the competition at the distant point as a ground for relief by the Commission from $\S 4$. See discussion accompanying notes 190-198 infra.

165 See Stuttgart Rice Mill Co. v. Alabama \& V. Ry., 93 I.C.C. 517, 530 (1924); Pacific Lumber Co. v. Northwestern Pac. R.R., 51 I.C.C. 738, 742 (1918); Eau Claire Board of Trade v. Chicago, M. \& St.P. R.R., 4 I.C.C. 65, 77 (1892); cf. Washington Potato \& Onion Shippers Ass'n v. Union Pac. R.R., 300 I.C.C. 537, 555 (1957); Consolidated Mining \& Smelting Co. v. New York Cent. R.R., 299 I.C.C. 23I, 244 (1956).

166 National Petroleum Ass'n v. Baltimore \& O. R.R., 126 I.C.C. 11, 16 (1927); Chicago

Gravel Co. v. Atchison, T. \& S.F. Ry., 118 I.C.C. 633, 645-46 (1926).

167 See discussion of group rate cases in Sharfman, THE Interstate Commerce Commission pt. III, vol. B, pp. 674-9I (1936); Comment, 98 U. PA. L. Rev. 204-09 (1949).

168 See Bituminous Coal to C.F.A. Territory, 46 I.C.C. 66, 143 (1917); Kansas City Transp. Bureau v. Atchison, T. \& S.F. Ry., 16 I.C.C. 195, 203 (1909); cf. Federated Metals Corp. v. Pennsylvania R.R., 161 I.C.C. 287, 288 (1930).

169 See Anaconda Copper Mining Co. v. Director Gen., 78 I.C.C. 549 (1923). See also 


\section{State Utilities Legislation}

Geographical economic discrimination in the case of electric and gas utilities may occur in one of two ways. Two purchasers located in different areas but served by the same utility may be charged differential rates which bear no relation to differences in cost, or, as is much more often the case, two geographically separated purchasers may be charged the same amount despite different costs of service. In general, the more distant the purchaser from the source of power, the greater the cost of providing the power to the purchaser. These differences primarily represent varying costs of delivery. Such cost differences may be augmented, or offset, by other distribution costs arising from relatively great or relatively low density of purchasers. The resulting uniformity is similar to uniform delivered prices in the sale of goods. While this uniformity lends itself to economic discrimination, it must be recognized that the billing costs involved in attempting to charge each customer with his precise share of the costs of delivery of the electricity might be so great as to outweigh any economic advantages to customers which might be associated with elimination of discrimination. ${ }^{170}$ In this sense, uniformity of electric rates may, to a certain extent, reflect the same administrative convenience consideration which may be found in group railroad rates. ${ }^{171}$

Public utility commissions have generally failed to take such cost factors into account and have favored system-wide uniformity of rates. ${ }^{172}$ Where commissions have sought to give some recognition to differences in the cost of delivery, they have usually limited their efforts to creating two or more broad rate zones. ${ }^{173} \mathrm{~A}$ common device is the creation of an

United States v. Illinois Cent. R.R., 263 U.S. 515 (1924). In addition to the economic discrimination involved in group rates, one recent empirical study suggests that on the whole "short-haul traffic does not make the same contribution to overhead as long-haul traffic." This relationship is attributed to the "higher elasticity of demand for short-haul railroad traffic ... created by truck competition." MEYER, THE EcoNOMiCS OF COMPETITION IN THE TRANSPORTATION INDUSTRIES 175 (1960).

170 Bonbright, Principles of Public Utility Rates 296-97 (1961).

171 See discussion in text at pp. 45-46 supra.

172 See Montana-Dakota Util. Co., 28 P.U.R.3d 355 (Mont. Pub. Serv. Comm'n 1959); Metropolitan Edison Co., 13 P.U.R.3d 29, 83-84 (Pa. Pub. Util. Comm'n 1956); Rates \& Rate Structures of Corporations Supplying Electricity in New York City, 1931C P.U.R. 337, 343 (N.Y. Pub. Serv. Comm'n I931); Kansas Gas \& Elec. Co., 1928E P.U.R. 634 (Kan. Pub. Serv. Comm'n 1928); Edison Elec. Illuminating Co., 1928D P.U.R. 859, 862-63 (Mass. Dep't of Pub. Util. 1928); Baird, Should the Rate Making Unit be Fixed by Statute, 1 U. CHI. L. REv. 451, 458 (1934); cf. Capitol Transit Co. v. Pub. Util. Comm'n, 213 F.2d 176, 182 (D.C. Cir. 1953); Potomac Elec. Power Co., 28 P.U.R.3d 206, 223 (D.C. Pub. Util. Comm'n 1959). But cf. Wabash Valley Elec. Co. v. Young, 287 U.S. 488 (1933). Two sets of uniform rates, one for urban areas and one for rural areas, are common. See, e.g., Alabama Power Co., 3 P.U.R. (n.s.) 355, 360-61 (Ala. Pub. Serv. Comm'n 1933).

173 See Welch, Cases on Public Utility Regulation 507-08 (1961). See also Warren 
urban and a rural zone. ${ }^{174}$ Rarely is there any systematic attempt to calculate the actual costs of delivery to individual purchasers or even to specific geographical areas. ${ }^{175}$

\section{The Role of Competition}

In the above discussion concerning the nature of economic discrimination, the question was raised whether that concept should be defined to include differential prices traceable to differences in the competitive situation between markets. ${ }^{176}$ The agencies administering the regulatory schemes under consideration here have not dealt directly with that question. They have, however, to one degree or another, taken competition into consideration either in the definition of the proscribed conduct or in the specification of affirmative defenses.

\section{A. Robinson-Patman Act}

The Robinson-Patman Act permits a seller to justify a price differential "by showing that his lower price . . . to any purchaser or purchasers was made in good faith to meet an equally low price of a competitor." 177 It is questionable to what extent this meeting competition defense actually serves to ameliorate the rigidifying effects on the distribution system of the act's proscription of price differentials. The circumstances under which a price reduction, however competitively motivated, may qualify for the meeting competition defense are quite limited. The fundamental qualification to the defense is that the seller may only meet, not beat, the equally low price of a competitor. This

v. Wisconsin Rapids, 45 P.U.R. (n.s.) 383 (Wis. Pub. Serv. Comm'n 1942). For a discussion of the Southern California Edison Company's six zone system, see Southern California Edison Co., 6 P.U.R.3d 161, 190-97 (Cal. Pub. Util. Comm'n 1954). It is true that where utility systems cover very large areas, some state public utility commissions establish utility districts within the state. Each district will then be a separate unit for ratemaking purposes. But the districts are relevant only for rate level regulation, the total revenues for each district being limited to a certain percentage of the rate base in that district. Districting is not normally an attempt to adjust rates to reflect differing costs of delivery.

174 See San Diego Gas \& Elec. Co., 26 P.U.R.3d 129, 142-44 (Cal. Pub. Util. Comm'n 1958); Missouri Edison Co., 22 P.U.R.3d 427 (Mo. Pub. Serv. Comm'n 1958); Missouri Power \& Light Co., 10 P.U.R. (n.s.) 8 (1935).

175 Utility Commissions may, however, require rates to reflect special taxes imposed by municipalities occupying less than the total sales territory. Cf. Village of Maywood v. Ill. Commerce Comm'n, 23 Ill. 2d 447, 178 N.E.2d 345 (1961); City of Elmhurst v. Western Gas Co., 363 Ill. 144, 1 N.E.2d 489 (1936); Arkansas Louisiana Gas Co., 40 P.U.R.3d 209, 215-17 (Ark. Pub. Serv. Comm'n 1961). Discrimination problems may arise from the generation by a single utility system of power in two or more geographically separated plants with varying cost characteristics.

176 See discussion at p. 8 supra.

177 Robinson-Patman Act, § 2(b), 49 Stat. 1526 (1936), 15 U.S.C. § 13(b) (1958). 
rule has several complicating applications. The seller may only reduce prices to his competitor's level and may not undercut that level, ${ }^{178}$ or in any event may not do so intentionally. ${ }^{179}$ In determining whether a competitor's price has been undercut, it is necessary to take into account not only the seller's low price but also the quality of his goods; if the seller has a premium product and the competitor has not, an equal price may be deemed a price which does more than merely meet competition. Since "premium" in this sense may refer merely to greater public acceptance-as, for example, that accorded a nationally advertised product -and not to any inherent superiority in quality, it will often be impossible for a seller to predict with certainty whether a court would treat a given price reduction as only meeting the competitor's price or as undercutting it. 180

Moreover, some courts have treated price reductions for the purpose of attracting new customers, as opposed to retaining old customers, as outside the scope of the meeting competition defense. ${ }^{181}$ The general principle suggested in dicta by the Supreme Court that the price met must be lawful ${ }^{182}$ has been applied to impose a burden upon the seller to show that the circumstances were such that a reasonable seller should reasonably have believed the competitor's lower price to be lawful. ${ }^{183}$ Further, the reduction in price must be made in response to a specific low price of a competitor within the context of rivalry for a specific customer and not as part of a pricing system. ${ }^{184}$ Finally, it is only a competitive

178 Standard Oil Co. v. FTC, 340 U.S. 231, 242, 247 (1951); Atlas Bldg. Prod. Co. v. Diamond Block \& Gravel Co., 269 F.2d 950, 957 (10th Cir. 1959).

179 Samuel H. Moss, Inc. v. FTC, I55 F.2d 1016 (2d Cir. 1946). See also Balian Ice Cream Co. v. Arden Farms Co., 231 F.2d 356, 366 (9th Cir. 1955); ATT'Y. Gen. NAT'L Comm. Antrtrust Rep. 183 (1955).

180 In Gerber Products Co. v. Beach-Nut Life Savers, Inc., 160 F. Supp. 916, 922 (S.D.N.Y. 1958), the "ultimate test" was stated to be "whether a substantial part of the public is prepared to pay a greater price" for the seller's than for the competitor's product. See also Anheuser-Busch, Inc., 54 F.T.C. 277 (1957), vacated, 265 F.2d 677 (7th Cir. 1959), remanded, 363 U.S. 536 (1960), on remand, 289 F.2d 835 (7th Gir. 1961); Pure Oil Co., No. 6640, FTC, Sept. 28, 1962; American Oil Co., No. 8183, FTC, June 27, 1962.

181 Standard Oil Co. v. FTC, 340 U.S. 231, 249-50 (1951); Standard Motor Prod., Inc. v. FTC, 265 F.2d 674 (2d Cir. 1959); cf. J.A. Folger Co., No. 8094, FTC, Sept. 18, 1962. But see Sunshine Biscuit, Inc. v. FTC, 306 F.2d 48 (7th Cir. 1962), setting aside FTC order, No. 7708, FTC, Sept. 28, 1961.

182 Standard Oil Co. v. FTC, 340 U.S. 231 (1951); FTC v. A.E. Staley MIfg. Co., 324 U.S. 746 (1945).

183 American Oil Co., No. 8183, FTC, June 27, 1962; Tri-Valley Packing Ass'n, Nos. 7225, 7496, FTC, May 10, 1962. See also Standard Oil Co. v. Brown, 238 F.2d 54 (5th Cir. 1956); Doubleday \& Co., 52 F.T.C. 169, 199 (1955).

184 See Standard Motor Prod., Inc. v. FTC, 265 F.2d 674, 677 (2d Cir. 1959); E. Edelmann \& Co., 51 F.T.C. 978 (1955), aff'd, 239 F.2d 152 (7th Cir. 1956). On the re- 
offer to the seller's customer, and not a competitive offer to that customer's customer, which will support a meeting competition defense, even though the seller's failure to lower his price must necessarily result in loss of the first customer's business. ${ }^{185}$

The cumulative effect of these many restrictions on the meeting competition defense is that the FTC has not yet sustained a single defense after commencement of formal proceedings.186 The few cases where defendants have successfully invoked this defense involved the setting aside by reviewing courts of FTC orders. ${ }^{187}$

\section{B. Interstate Commerce Act}

In considering the role of competition as a defense under the Interstate Commerce Act, several distinctions must be kept in mind. One distinction involves the geographical source of the competition. Thus, competition may come from carriers serving the same points of origin and destination as the defendant railroad; such competition may be called carrier competition. 188 On the other hand, the competition may be provided by carriers serving a common point of destination but a different point of origin (or, less frequently, a common point of origin and a different point of destination). This second kind of competition is sometimes called "market competition" to emphasize that in one sense rival producing areas are competing for the trade of a common consuming center (or rival consuming centers for the production of a common producing center). But use of that term should not be permitted to obscure the fact that the focus of the competition is between carriers which, through lowering of rates, attempt to stimulate increased traffic over their respective lines. Another fundamental distinction is among the types of carriers providing the competition. Thus, depending on the context, the availability of a meeting competition defense may turn on whether the rival carrier is another railroad or some other mode of carriage and whether, in the latter case, the rival carrier is under the regulation of the ICC. Finally, the availability of competition as a defense will differ with the type of discrimination charged.

Where the charge is one of personal discrimination-that is, where the

lated point that the seller must have had actual knowledge of a competitor's lower offer to the buyers in question, see Forster Mfg. Co., No. 7207, FTC, Jan. 3, 1963.

185 FTC v. Sun Oil Co., 371 U.S. 505 (1963).

186 See Handler, Recent Antitrust Developments, 71 YaLE L.J. 75, 102-03 (1961); Rowe, Expectation Versus Accomplishment Under the Robinson-Patman Act, 19361960, 17 ABA Section on ANTITRUST LAw 298, 306 (1960).

187 E.g., FTC v. Standard Oil Co., 355 U.S. 396 (1958).

188 It is also called "competition of routes." See Locklin, Economics of TransportaTION 183 (5th ed. 1960). 
defendant carrier is alleged to have charged different rates for the carriage of a single commodity between common points of origin and destination-the general principle is that no meeting competition defense will be recognized. Section 2, which governs such cases, contains no explicit meeting competition defense and decisions interpreting that section have established that competition is not a factor to be considered in determining whether a "like kind of traffic" is carried under "substantially similar circumstances and conditions." 189 As has been observed, the ICC has nevertheless comparatively recently permitted rail carriers to grant single shipment volume discounts where necessary to meet the competition of another mode of carriage, and multiple shipment volume discounts where necessary to meet competition from modes not subject to ICC regulation (subject in each case to certain other requirements previously discussed ${ }^{190}$ ). No distinction is made between carrier and market competition. It is the combination of the greater volume and the competition, rather than the competition itself, which is deemed to create the requisite dissimilarity.

Where the alleged discrimination is between hauls-that is, where two hauls of a like commodity have different points of origin or destinationthe general principle is that such a geographical differential may be justified by a showing that the differential was essential to meet competition of another rail carrier or another mode of transportation. ${ }^{191}$ No explicit distinction is made between carrier and market competition, although the ICC appears to be somewhat more receptive to defenses based on carrier than on market competition. This right to meet competition is qualified, however, in a number of important respects. First, meeting competition is not a defense to a differential if the competition in question is present at both the favored and disfavored points, and this is so even though there is a substantial difference in degree in the competition at the two points. ${ }^{192}$ Second, where competition is presented at some, but not all points of origin (or destination), the competition must be met wherever presented or not met at all. ${ }^{193}$ Thus, the meeting

189 Seaboard A.L. Ry. v. United States, 254 U.S. 57 (1920); Wight v. United States, 67 U.S. 512 (1897).

190 See discussion at pp. 23-25 supra.

191 See, e.g., Cotton Linters from Tex. to La. \& Tex. Ports, 237 I.C.C. 425, 430-31 (1940); Canned Goods from Savannah to Ga., 237 I.C.C. 175, 180 (1940).

192 See, e.g., Iron and Steel to Iowa, Minn., Mich., \& Wis., 297 I.C.C. 363, 388-89 (1955).

193 See Iron \& Steel to Iowa, Minn., Mich. \& Wis., 297 I.C.C. 363, 388 (1955); Meats \&: Packing House Products from Chicago to C.F.A. Territory, 237 I.C.C. 525, 541 (1940); Cotton Piece Goods in the South, 234 I.C.C. 525, 534 (1939); Princeton Mining Co. v. Algers, T. \&. W. Ry., 205 I.C.C. 737, 739 (1934); Memphis Freight Bureau v. Louisville Ry. \& Nav. Co., 194 I.C.C. 269, 272 (1933); Bunker Hill \& Sullivan Co. v. OregonWashington R.R. \& Nav. Co., 132 I.C.C. 266, 271 (1927). 
competition defense under the Interstate Commerce Act does not make legitimate the isolated, sporadic reductions which the FTC considers to be the only reductions appropriate for absolution under the meeting competition defense, but rather only systematic reductions applicable uniformly to all points where competition is encountered. ${ }^{194}$ Finally, the ICC has sometimes been unwilling to permit a reduction to meet competition where the effect would be to upset long established parity of rates from competing points of origin or other well established rate relationships. ${ }^{195}$

Two different kinds of competition may serve as a defense to a charge of violation of section 4, the Long-and-Short-Haul clause. Competition from another rail carrier will usually lead to charging more for a short than for a long haul under the circumstances specified in section 4 only where the defendant railroad has a more circuitous route than the competing railroad. ${ }^{196}$ Prior to 1957 circuity was one of the major circumstances permitting the ICC to grant relief from section 4 and in that year section 4 was amended to permit rail carriers "operating over a line or route" to "meet the charges of ... carriers of the same type operating over a more direct line or route" without seeking approval by the Commission. ${ }^{197}$

Where the competition stems from some circumstance other than circuity, application must be made to the ICG for relief from section 4 . Most applications for approval cite the competition of water or motor carriers and here the standards are much the same as those governing competition as a defense under section 3. Thus, proof of injury and proof that competition was met at all points presented are required. ${ }^{198}$ Market competition is, however, only infrequently a basis for section 4 relief because, whether one is concerned with the competition of origin or destination areas, localities at intermediate points on the applicant's line will usually need a rate not lower than the locality at

194 See discussion at p. 50 supra. Moreover, the ICC allows the meeting of potential, rather than presently existing competition. See Ethylene Glycol from Tex. to the East, 288 I.C.C. 785, 789 (1953); Petroleum Haulers v. Boston \& Me. R.R., 269 I.C.C. 6, 9 (1947); cf. Alcohol from Ill. \& Ind. to Texas City, Tex., 273 I.C.C. 555, 561 (1949).

105 See Meats from Oklahoma City, Okla. to Ark., Mo. \& Tenn., 238 I.C.C. 625 (1940). See also Petroleum Products from Wyo. to Mont., 276 I.C.C. 721 (1950).

196 See the discussion of the geography of circuity in LockLIN, Economics of TransPORTATION 470-72 (5th ed. 1960). Of course, competition from another rail carrier may lead to $\S 4$ problems where both railroads are of equal length and, while serving the same end points, do not secure the same intermediate points. Here competition with respect to rates between the end points will drive rates below those from an end point to the intermediate points. See $i d$. at $468-70$.

19771 Stat. 292 (1957).

198 See generally Sharfman, The Interstate Commerce Commission pt. III, vol. B, pp. 572-625 (1936). 
the end of that line in order to compete with localities located on a rival line. 198

A meeting competition defense is also available with respect to charges of discrimination among commodities. Though two commodities are sufficiently closely related that a differential in rates would be unlawful, or so that the Commission would prescribe a fixed differential, the existence of competition from competing carriers with respect to one but not the other commodity will justify an otherwise unlawful differential.200

Whatever the context in which a meeting competition defense may be advanced, the power of rail carriers to reduce rates in order to meet competition is subject to several overriding statutory policies imported from parts of the act not dealing directly with discrimination. Thus, without regard to the extent of competition, the low rate must not be reduced below a "just and reasonable" level prescribed by section 1, which means in general that the reduced rate must remain compensatory. ${ }^{201}$ More particularly, where the competition comes from a different mode of transportation which is subject to ICC regulation, such as from a water or motor carrier, the right to meet such competition is circumscribed by the ICC's power to prescribe minimum rates to preserve the "inherent advantages" of competing modes of transportation. ${ }^{202}$

199 See discussion of cases in LockLin, Economics of Transportation 479, 517 (5th ed. 1960); Comment, 45 Yale L.J. 1426, I452-55 (1936).

200 See, e.g., Fertilizer from Baltimore to Various Eastern States, 238 I.C.C. 563, 567 (1940); Meats \& Packing House Products from Chicago to C.F.A. Territory, 237 I.C.C. 525, 537 (1940); National Veneer \& Panel Mfrs. Ass'n v. Aberdeen R.R., 195 I.C.C. 411 (1933); Atlas Cereal Co. v. Atchison, T. \& S.F. Ry., 89 I.C.C. 212, 218 (1924).

20124 Stat. 379 (1887), 49 U.S.C. \$ 1 (1958).

202 See notes $42-43$ supra. The meeting competition decisions of the ICC highlight a particular dilemma to be faced in stating ICC policy toward competition as a defense. In view of the many applicable distinctions, which appear to be somewhat more complex than those applied under the Robinson-Patman Act, one might expect that the decisions of the ICC would have provided relatively precise guidelines concerning the conditions under which competition will justify differentials under $\S 3$. But unfortunately opinions, particularly the more recent ones, do not illuminate. To the extent that rules are stated, they tend to be stated so generally that one cannot be confident that they provide a guide for the future. Thus, ICC pronouncements on competition frequently create a grey area in which competition may or may not be approved, depending apparently on the ipse dixit of the Commission. Thus, the Commission has said, "It is fundamental, of course, that carriers may reduce their rates to meet competition, provided the reductions are not below a minimum reasonable level and they do not create undue preference or prejudice." Iron and Steel to Iowa, Minn., Mich. \& Wis., 297 I.C.C. 363, 388 (1955). Thus, we are in effect told, rate differential designed to meet competition shall not be deemed to create undue preference or prejudice under $\S 3$ unless they create undue preference or prejudice, a hardly helpful formulation. See Report on Regulatory Agencies to the President-Elect (LANDIS REPORT) 39 (1960) ("Opinions of the Interstate Commerce Commission are presently in the poorest category of all administrative agencies. Their source is un- 


\section{State Utilities Legislation}

The prohibitions against discrimination in state public utilities statutes do not, strictly speaking, admit of a meeting competition defense. It would be wrong, however, to conclude that the commissions which enforce such legisiation have been hostile to rate differentials designed to meet competition.

Any discussion of competition in the electric power field must recognize that competition among electric power companies is, as we have seen, ${ }^{203}$ relatively rare. Whether this absence of competition stems from economies of scale or from licensing policies of state utilities commissions, it nonetheless profoundly affects the role of competition as a defense to a discrimination charge.

Electric power companies face a great deal of competition, however, from other sources of energy, such as oil, natural gas, bottled gas and coal, and, in the case of sales to industrial consumers, from private electric power generation facilities. ${ }^{204}$ The only major fields generally free from such competition are residential and commercial lighting. State utility commissions permit construction of schedules designed to give the utilities a rate advantage over such competing forms of energy. For example, low rates to large industrial customers capable of constructing private power plants are favored even though rates to residential customers are higher; the resulting differentials are not required to be cost justified. Block schedules are approved which impose high rates on residential consumers to the extent of estimated lighting requirements-a demand for which the electric power companies have a monopoly-but sharply reduced rates for additional residential demands, such as cooking and heating, for which the electric power companies face sharp competition. ${ }^{205}$ Utility commissions frequently favor, for example, sharply reduced "promotional rates" designed to induce residential consumers to use electric power for new purposes. Special rate meters attached to the appliance involved in the competitive use (such as electric water heaters, electric furnaces and so forth) may permit the utility to meet the competition charges of alternative forms

known and the practice has grown up of parsimony in discussing the applicable law in making a determination. Lengthy recitals of the contentions of the various parties are made as a prelude to a succinct conclusion devoid of real rationalization."). Cf. Hector, Problems of the $C A B$ and The Independent Regulatory Commissions, 69 YALE L.J. 931, 942-43, 947-48 (1960).

203 See discussion in text accompanying notes 54-55 supra.

204 Edison Elec. Illuminating Co., 1928D P.U.R. 859, 862 (Mass. Dep't Pub. Util. 1928); Southern California Edison Co., 38 P.U.R. (n.s.) 116 (Cal. R.R. Comm'n 1941). 205 Cf. Alabama Power Co., 3 P.U.R. (n.s.) 355, 360-64 (Ala. Pub. Serv. Comm'n 1933). See also Gaywood, Electric Utility Rate Economics 44 (1956). 
of energy with more precision than block schedules; this technique assures that the benefit of the low rate will be secured by the consumer only for the competitive use and not for noncompetitive uses, albeit the additional meters impose an additional cost of service. ${ }^{206}$

Thus, while the statutes do not specify that meeting of competition should be a defense to a charge of discrimination, rates designed to meet such competition are treated as nondiscriminatory. ${ }^{207}$

\section{Some Comparisons in Method and Purpose}

Review of three specific practices-quantity discounts, classification of customers and geographical differentials-and of rules concerning meeting competition reveals several sharp differences in the impact of the regulation, particularly when the respective agencies' interpretation and method of enforcement of the statutes are taken into account. Thus, with respect to quantity discounts, state public utility commissions give such discounts rather enthusiastic approval; the FTC permits them only where their basis in differential costs can be demonstrated with precise cost data; and the ICC prohibits them unless, in the case of single shipment, multiple carload discounts, the differentials are "reasonably related," and the lower rates help railroads to compete with other transportation modes or, in the case of multiple shipment volume discounts, they help railroads compete with modes of transportation not subject to ICC regulation. Again with respect to classification of customers, state public utility commissions tend to favor broad classifications of customers, the FTC tends to permit classifications where competition between sellers is not seriously deranged unless such classification might injure particular resellers in the chain of distribution, and the ICC, while purporting to proscribe such classifications, encourages them in fact through the device of classification of commodities and thereby encourages economic discrimination. Turning to geographic differentials, state public utility commissions have tended, with limited exceptions, to discourage such differentials even where a policy of eliminating economic discrimination would require rate differentials in view of differences in costs of delivery; the FTC has not been greatly concerned with such differentials except where it suspected that a large national seller was trying to drive local competitors out of business; and the ICC, while purportedly greatly concerned with eliminating discrimination

206 Cf. New York State Elec. \& Gas Corp., 6 P.U.R. (n.s.) 113 (N.Y. Dep't of Pub. Serv. 1934).

207 See Southern California Edison Co., 38 P.U.R. (n.s.) 116 (Cal. R.R. Comm'n 1941) (competition from private generation); Modesto Irrigation Dist. v. Pacific Gas \& Elec. Co., 1932B P.U.R. 203 (Cal. R.R. Comm'n 1931) (geographical differential). 
arising from geographic differentials, has in many cases tended to approve economic discrimination through group rate practices.

A review of these differences of approach reveals several common policies of the agencies. First, the agencies strongly favor the status quo in industry organization; they have sought to preserve the position of existing firms, however economically unjustified, even to the point of requiring economic discrimination to preserve them. In the case of the FTC, the concern has been primarily for resellers and for local sellers faced with national competition. In the case of the ICC and state utility commissions, the concern has been more for the promotion of the firms under regulation, except in the case of the ICC, to the extent that its regulation extends to competitors of the rail carriers. Second, with respect to the agencies regulating specific industries-and particularly the ICC-a desire to engage in a form of economic planning, and not merely to act as an enforcement agency for rules established by the legislature, has been particularly strong. Finally, these latter agencies have tended to favor the interests of the firms being regulated at the expense of competing firms not subject to their jurisdiction. Thus, the ICC permits volume discounts only where necessary to meet nonregulated competition and the state public utility commissions have encouraged economic discrimination by electric power companies where necessary to meet the competition of alternative forms of power.

The methods and purposes of administration of the three statutory schemes under discussion merit closer examination.

\section{A. Robinson-Patman Act}

The FTC has been primarily concerned with preserving the existing distribution system. In furtherance of that objective the FTC has tended to give the Robinson-Patman Act an "equal opportunity" interpretation. The Robinson-Patman Act has been construed to give manufacturers considerable latitude in differential pricing except where they quote different prices to competing resellers, such as wholesalers or retailers. While it has permitted functional discounts, such discounts tending to preserve rather than to disturb the existing distribution system, it has scrupulously insisted that the purchaser's function be determined by the level at which he resells rather than by the functions he performs in buying, thereby protecting existing wholesalers and retailers from competition by more efficient integrated wholesaler-retailers which have appeared more recently on the marketing scene. That the FTC should have chosen to preserve the existing distribution system at the expense of eliminating discrimination is not surprising when one reviews the legislative history of the Robinson-Patman Act. The initial impetus came from 
the United States Wholesale Grocers' Association at a time when the position of wholesale grocers was being threatened by the growth of chain grocery stores which combined retail and wholesale functions. Strong support followed from retail grocers, retail druggists and food brokers, who also were being challenged by more efficient marketing methods. 208

In regulation of geographical price differentials where the purchasers are not in competition, the FTC has restricted its enforcement activities to situations where local sellers face strong competition from a national seller. Here again the motif of FTC policy appears to be an "equal opportunity" notion under which the local sellers' position is to be protected against what is viewed as the unfair pricing practices of the national firm.

In no aspects of its enforcement activities reviewed here, either with respect to the three pricing practices reviewed or in its treatment of the meeting competition defense, has the FTC shown any notable degree of understanding of the phenomenon of economic discrimination.

\section{B. Interstate Commerce Act}

Systematic economic discrimination by railroads was well developed at the commencement of ICC regulation in 1887. The Commission's energy, as far as discrimination is concerned, has been largely directed at personal and geographical differentials with relatively little interest demonstrated in discrimination among commodities, although the incidence of economic discrimination is probably far greater in the last area than in the other two. The energy directed at personal and geographical differentials has largely missed the mark, if economic discrimination is the phenomenon to be regulated. While some economic discrimination has been eliminated in cases of personal differentials, the terms of section 2 have also been applied to require economic discrimination in the case of cost savings from quantity shipments. The Commission, as we have seen, originally required uniform rates even in the absence of uniform costs. To the extent that the stringency of the quantity discount rules has been broken down since 1939, the liberalizing influence cannot be attributed to rising sensitivity on the part of the Commission to the nature of economic discrimination but rather, with respect to single shipment quantity discounts, to greatly increased truck and barge competition tending to weaken seriously the economic health of the railroads and, in the

208 The legisiative history is reviewed at length in Rowe, Price Discrimination Under the Robinson-Patman Act 11-23 (1962). See also Patman, Complete Guide to THE Robinson-PatMan ACT 196-202 (1963), for Representative Patman's list of the "Supporters of the Act." 
case of multiple shipment volume discounts, to the competitive pressures of nonregulated competition.

The history of the rules on quantity differentials reveals an interesting conflict of values. Until 1939 the ICC was content to apply section 2 where necessary to secure equal opportunities for small shippers as against large shippers. The carload-LCL differential was viewed as a relatively harmless restriction on equal opportunity for shippers because most small shippers were able to ship at least one carload at a time. But the rise of competition from competing modes began to produce a serious conflict in ICC policies, for the Commission also viewed its job as one of promoting railroad traffic, and the inability to quote multiple carload discounts threatened the railroads with loss of traffic. But as trucks and barges were also put under ICC jurisdiction, the conflict in policies became more complicated because now the Commission was also dedicated to the goal of promoting truck and barge traffic. The National Transportation Policy suggests the dimensions of the conflict. Among the congeries of policies to be furthered, the ICC is to "foster sound economic policies in transportation and among the several carriers," while "preserv[ing] the inherent advantages of each" of the modes, "all to the end of developing, coordinating, and preserving a national transportation system by water, highway, and rail." Thus, equal opportunities for small shippers are to be subordinated to promotion of railroad traffic in the face of competition, but, to balance the need to promote rail traffic against the simultaneous need to promote truck and barge traffic, multiple shipment volume discounts are to be limited to situations where the competition comes from modes not subject to ICC regulation.

In the rules governing geographical differentials, we have seen the same preference for preserving equal opportunities for shippers over eliminating economic discrimination. Here grouping of rates has been approved and even encouraged, in part on the theory that the distant shipper should be able to compete on equal terms with the closer shippers whether or not economic efficiency would thereby be improved. ${ }^{209}$

209 Geographical discrimination may also be approved by the ICC in an effort to be fair to all carriers: "[Geographically] price discrimination originates in large part from efforts to allow each railroad to share in the available traffic. Thus, a carrier indirectly connecting such terminals as San Francisco and Chicago may be permitted, by a grouping of rates or a long-haul-short-haul exemption, to set special rates in order to compete with carriers directly serving these points, even though these rates are unrelated to the cost differences between serving this traffic and the carriers' other traffic. From the viewpoint of the individual carrier, these special rates may be profitable since they exceed the marginal costs of the additional traffic. . . . But for transportation systems as a whole such price discrimination may simply increase the excess capacity and thus the costs of the other railroads serving the city pairs directly. Since 
To what can we attribute the ICC's lack of interest in discrimination among commodities? The ICC has so freely condoned such economic discrimination that there is evidence that the degree of discrimination is increasing with the passage of time.210 It has sought to construct an intellectual defense for such discrimination through its espousal of the value-of-service doctrine. No single reason can be advanced, however, to explain the Commission's encouragement of value-of-service discrimination. The system was in effect at the creation of the ICC in 1887, and the fledgling agency probably found it easier not to attempt to change existing patterns in view of the profound effects such change might have on the economic fortunes of localities and industries throughout the country. ${ }^{211}$ Second, while cost information with respect to particular rates is of dubious reliability today, it was almost nonexistent in the days when the ICC was forming its basic policies. To utilize the statutory provisions to eliminate economic discrimination thus posed difficult practical problems. ${ }^{212}$ Third, value-of-service arguably served an overriding national interest in the early years of the Commission when traffic for westward expanding railroads could be created in the remaining undeveloped areas of the United States by very low rates for agricultural and mineral shipments while rates were maintained at a much higher level relative to costs for the products of Eastern manufacturers. To prohibit such discrimination among commodities might have been to slow the economic development of the West. ${ }^{213}$ Here the desire to promote railroad traffic merged in the patriotic desire to promote the westward growth of the nation.

None of those three reasons excuses, or even explains, the ICC's continued encouragement of value-of-service discrimination. Perhaps they do, however, reveal a regulatory syndrome that has persisted. The urge to play the planner is strong in regulatory agencies, suffused as they are

it obviously costs more to haul traffic on the longer routes, the result is to increase the total costs of the transportation industries." MEYER, op. cit. supra note 169, at 182-83.

210 The evidence is summarized $i d$. at $180-81$.

211 See Evans v. Oregon Ry. \& Nav. Co., 1 I.C.C. 641, 646 (1887); 1 ICC ANN. REP. $10,19,40$ (1887). See also Sharfman, op. cit. supra note 198, at 414-16.

212 "The cost of the transportation of any one article of commerce over the line of a public railway can never be arrived at with anything like accuracy .... Should the attempt be made to make [an] apportionment as between the various kinds of freight carried, the elements of uncertainty that would necessarily be dealt with would increase and multiply at every step. If the carrier desired to make the cost of any particular traffic appear large or appear small, it would not be difficult to swell it or to lessen it by such figures as would appear perhaps equally plausible in each case, but which, nevertheless, would not be such in either case as ought to determine the rights of third persons." Haddock v. Delaware, L. \& W. R.R., 3 I.C.C. 302, 311 (1890).

213 See MEXER, op. cit. supra note 169, at 179. 
with the spirit of their own expertise. ${ }^{214}$ The ICC believes that value-ofservice ratemaking serves the interests of the economy. Its reasons, while not very well thought out and while lacking in understanding of the economics of price discrimination, are nonetheless plausible to the casual observer. If rates on manufacturers were not high, so sayeth the Commission, traffic in low-valued commodities such as coal could not move under the higher rates which would then be necessary. Thus, the desire to promote railroad traffic has led the ICC to encourage railroads to engage in economic discrimination on a grand scale.

\section{G. State Public Utilities Legislation}

State utility commissions have not been notably sensitive to discriminatory practices by electric power companies. Differential charging is viewed as desirable, except to customers who are indisputably in like situations, and as consistent with the commissions' "promotional" interpretation of the regulatory legislation. Indeed, the commissions have stimulated a good deal of economic discrimination by encouraging quantity discounts and classification of customers and by permitting uniform system-wide rates within each rate classification. Approval of the latter type of discrimination may be laid partly to considerations of rate quoting convenience and partly to a misconception of the nature of economic discrimination, but in the case of quantity discounts and customer classification, a few of the more perspicacious commissions appear to recognize that they are promoting economic discrimination.

Since the opinions of utility commissions do not, with rare exceptions, discuss the reasons underlying decisions or make any attempt to build an articulated body of legal doctrine, it is a highly speculative endeavor to seek the reasons for this favoritism toward economic discrimination. Several factors may be suggested. Electric power companies are usually monopolies in the sense that only one electric power company is permitted to serve a given area. They are, moreover, firms which are thought to operate with marginal costs which decline sharply with increases in output. Without attempting to verify that assumption, or to discuss the circumstances under which the reasoning is likely to be correct, one can

214 This urge is clearly reflected in some of its decisions on the reasonableness of individual rates, e.g., Wool \& Mohair Rates, 276 I.C.C. 259 (1949) (economic condition of sheep business to be considered in setting wool and mohair rates); Peaches from the South to Official Territory, 270 I.C.C. 573, 582 (1948) (reduced rates for peaches necessary to provide relief to peach industry); Alden Coal Co. v. Cent. R.R., 263 I.C.C. 639, 655-56, 656-57 (1945) (economic health of anthracite coal industry should be considered in determining rates for anthracite coal); American Potash \& Chem. Corp. v. Aberdeen \& R. R.R., 258 I.C.C. 743, 757 (1944) (rates on fertilizer should be kept low to stimulate agricultural production). See also Anchor Coal Co. v. United States, 25 F.2d 462 (S.D.W. Va. 1928). 
merely observe that the commissions appear to draw the conclusion that by lowering rates in order to lure business away from competing forms of energy or by creating new uses for electric power, the increased output will tend to make possible lower rates for all purchasers and not merely for the favored purchasers. ${ }^{215}$ Such is indeed a possible result. ${ }^{216} \mathrm{But}$ whether it is the usual result of discrimination arising from quantity discounts and classification of consumers is an empirical problem beyond the scope of this paper.

Several other factors might be noted. If it is conventional to treat electric power companies as monopolies, it is nonetheless misleading. Such firms face substantial competition from other forms of energy-natural gas, bottled gas, oil and coal-as well as from industrial generating plants and, occasionally, from municipal and federal power systems and other private electric power companies. ${ }^{217}$ Only natural gas is customarily regulated by the state commissions with jurisdiction over electric power. The commissions, in attempting to promote consumption of electric power, may tend to favor the electric power companies at the expense of nonregulated competitors (or competitors regulated by other agencies). For example, lower rates to industrial than to residential consumers may merely reflect a desire to meet competition from alternative forms of energy and from private generating plants; such competition is felt more strongly in the case of industrial sales than residential sales. Further, certain quantity discounts may reflect an attempt to take business away from competing forms of energy. Thus, certain utilities have recently added additional low rate blocks to their block schedule in order to encourage home owners to switch to electricity for heating purposes.

These observations lead to rather melancholy conclusions concerning the present status and future possibilities of statutes regulating price discrimination. The agencies involved do not appear to comprehend the nature of the economic phenomenon purportedly being regulated. In many instances the regulation tends to promote economic discrimination: The statutory schemes tend to be construed as equal opportunity or promotional statutes and are administered either to protect existing firms or to grant sellers an informal license to practice economic discrimination.

One is forced to conclude that whatever arguments may be advanced 215 See Wholesale Rates for Electric Power to Rural Cooperatives, 19 P.U.R. (n.s.) 22, $29-30$ (Ky. Pub. Serv. Comm'n 1937).

216 See Bonbright, Principles of Public Utility Rates 309 (1961).

217 See Caywood, Electric Utility Rate Economics 5 (1956). 
in support of anti-discrimination legislation, one cannot say that an economic objective is served. The economic practice supposedly under regulation is not discouraged and may indeed on balance be encouraged. Legislation so long on the books is not to be condemned, of course, merely because the only supporting considerations involve abstract social and political values. One would have to undertake a searching inquiry into the notion of equality in a market economy in order to be satisfied that such legislation was unjustified. In the meantime, the social and political values the statutes purport to embody may deserve to be taken seriously, if only on the practical ground that it is precisely the strength of these values which has enabled anti-discrimination statutes to survive massive criticism. Barring a great change in the popular notion of economic equality, perhaps the most that can be hoped is that regulatory agencies will come to understand better the nature of economic discrimination. These agencies have a wide range of discretion to reorient the administration of anti-discrimination legislation in order to attack more directly the practice of economic discrimination. 